\title{
EFFECT OF KINETIN AND MINERAL FERTILIZATION ON GROWTH FLOWERING, BULBS PRODUCTIVITY, CHEMICAL COMPOSITIONS AND HISTOLOGICAL FEATURES OF Hippeastrum vittatum PLANT Youssef, A.S.M.* and M.M.M. Abd El-Aal ${ }^{* *}$ \\ ${ }^{*}$ Horticulture, Dept. Fac. of Agric., Benha University. ${ }^{\star *}$ Agricultural Botany Dept. Fac. of Agric., Benha University.
}

\begin{abstract}
Two field trials were carried out to study the effect of 16 treatments represented the combination between four concentrations of kinetin $(0.0,20,40$ and $60 \mathrm{ppm}$.) and four levels $(0.0,2,4$ and $6 \mathrm{~g} / \mathrm{plant})$ of mineral fertilization on the growth, flowering, bulb productivity, chemical composition and histological features of Hippeastrum vittatum plant.Results showed that all tested kinetin concentrations statistically improved vegetative growth parameters i.e., plant height, number of leaves, leaves fresh weight and leaves dry weight, flowering growth parameters i.e., flowering start, inflorescence length, flowering stem diameter and inflorescence fresh weight, bulb growth parameters i.e. bulb diameter, fresh and dry weight of bulb, number and diameter of bulblets, chemical composition parameters i.e., N, P, K, total carbohydrates and total chlorophylls contents as well as endogenous phytohormones i.e. cytokinins, gibberellins, auxin (IAA) and abscisic acid (ABA) and histological features of Hippeastrum vittatum leaf with superior to the medium and high rates.

Also, all mineral fertilization levels significantly improved the aforementioned parameters, especially the high levels. Additionally, most the combinations of kinetin concentrations and levels of mineral fertilization improved all the studied parameters, particularly combinations between kinetin at $60 \mathrm{ppm}$ and mineral fertilization at 6 $\mathrm{g} / \mathrm{plant}$ in both seasons. As for the anatomical studies, several alternations were existed with different applied treatments. Most of the combinations between kinetin concentrations and levels of mineral fertilization gave the highest parameters values in transfer sections of the blade as compared with the control. The most effective treatment was kinetin at $60 \mathrm{ppm}$ combined with mineral fertilization at $6 \mathrm{~g} / \mathrm{plant}$.

Conclusively, spraying Hippeastrum vittatum plants with kinetin at $60 \mathrm{ppm}$ and mineral fertilization with $N: P: K$ at the ratio of $2: 1: 2$, respectively induced prospective effects on vegetative growth and flowering parameters with higher bulbs productivity.

Keywords: Hippeastrum vittatum, growth, flowering, chemical constituents and histological features.

Corresponding Author: E-mail: ahmed.youssef@fagr.bu.edu.eg
\end{abstract}

\section{INTRODUCTION}

The flowering bulbous plants are considered as a group of the most beautiful adjuncts for garden decoration. They are used particularly in landscape, production of commercial cut-flowers and act as a source of glorious colors and perfumes. Hippeastrum vittatum, Herb. cv. Apple Blossom belongs to the Family Amaryllidaceae. Apple Blossom has pretty pink bloom with white striping. Very strong grower, large spectacular trumpet shaped. The most popular genus is Hippeastrum, usually called 
Amaryllis. Hippeastrum vittatum, Herb. is categorized as winter flowering ornamental bulbs, monocotyledon, herbaceous plant. It is grown in Egypt for outdoor, as a flower bed impact and in borders, as well as, for cut flowers and indoor, as a pot plant. Amaryllis has no actual rest-period if grown in warm weather as that of Egypt in which it keeps its foliage evergreen all over the year. The inflorescence emerges under Egypt temperature in MidApril and lasts for a limited short period i.e. 2 -4 weeks (Everett, 1991).

Many authors demonstrated that growth and flowering of many ornamental bulbs are greatly influenced by different growth regulators among which kinins group. Kinetin is recognized by its ability to induce cell division in certain plant tissues (Cheema and Sharma, 1982) it can also overcome the apical dominance of many plants and stimulate the lateral buds to develop into an entire new plant. Kinetin can delay senescence and cause transport of many solutes from older parts of the leaves or even from older leaves into the treated zone (Salisbury and Ross, 1974). In this respect, Youssef and Ismaeil (2009) indicated that 200 ppm kinetin-sprayed plants improved all studied vegetative and flowering growth traits of Clivia miniata plants. Additionally, Youssef and Mady (2013) cleared that spraying Aspidistra elatior plants with benzyladenine at $75 \mathrm{ppm}$ improved all tested vegetative and chemical constituents of this plants.

Most bulbs need more than two applications of fertilizers during the growing season, but the most important point is that the greatest increase in size and weight of the new developing bulb takes place in the period during and mostly after flowering, as long as the foliage remains in good condition. Thus, fertilization must continue for good vegetative growth to produce a good flower and large new mature bulbs (Rees, 1992). In this concern, ElMalt et al. (2006) indicated that treating Hippeastrum vittatum plants with chemical fertilizer (NPK) at $5 \mathrm{~g} /$ pot improved the vegetative and flowering growth. Moreover, El-Nagar and El-Nasharty (2009) revealed that fertilized Hippeastrum vittatum with mineral fertilization at $5 \mathrm{~g} /$ plant gave the maximum beneficial effect on the vegetative growth characteristics, flowering, bulb and bulblets production. Thereupon, this study was undertaken to evaluate the effect of kinetin and mineral fertilization (NPK) on growth, flowering, bulblet productivity, chemical composition and histological features of Hippeastrum vittatum plant.

\section{MATERIALS AND METHODS}

This investigation was carried out in the open field at the Floriculture Nursery of the Horticulture Department and the Laboratory of Agriculture Botany Dept., Faculty of Agriculture at Moshtohor, Benha University, during $2010 / 2011$ and $2011 / 2012$ seasons to study the ability of kinetin treatments $(0,20,40$ and $60 \mathrm{ppm})$ and some chemical fertilization treatments $(0,2,4$ and $6 \mathrm{~g} /$ plant) in combining treatments to lump their benefits in producing high quality flowers and increasing the plant productivity of the new Hippeastrum bulblets. 


\section{Plant material:}

Bulbs of Hippeastrum vittatum, cv. Apple Blossem plants at the weight of $150-165 \mathrm{~g}$ and with an average diameter of $6.9-7.6 \mathrm{~cm}$. were obtained freshly from Floriculture Nursery of the Horticulture Department, Faculty of Agriculture at Moshtohor, Benha University.

\section{Planting procedure:}

Bulbs of Hippeastrum vittatum plants were planted in clay loam soil "(the analyses of the used soil are presented in Tables $(a, b) "$ on mid September in beds $1 \times 1 \mathrm{~m}^{2}$ as every bed contain 4 bulbs planted at $50 \times 50 \mathrm{~cm}$ in between in both seasons.

Table (a): Mechanical analysis of the experimental soil.

\begin{tabular}{|l|c|c|c|}
\hline \multirow{2}{*}{ Parameters } & \multirow{2}{*}{ Unit } & \multicolumn{2}{|c|}{ Seasons } \\
\cline { 3 - 4 } & $\%$ & $\mathbf{2 0 1 0 / 2 0 1 1}$ & $\mathbf{2 0 1 1 / 2 0 1 2}$ \\
\hline Coarse sand & $\%$ & 5.14 & 4.89 \\
\hline Fine sand & $\%$ & 15.92 & 16.37 \\
\hline Silt & $\%$ & 26.45 & 27.04 \\
\hline Clay & $\%$ & 52.49 & 51.70 \\
\hline Textural class & ------ & Clay loam & Clay loam \\
\hline
\end{tabular}

Table (b): Chemical analysis of the experimental soil.

\begin{tabular}{|l|c|c|c|}
\hline \multirow{2}{*}{ Parameters } & \multirow{2}{*}{ Unit } & \multicolumn{2}{|c|}{ Seasons } \\
\cline { 3 - 4 } & & $\mathbf{2 0 1 0 / 2 0 1 1}$ & $\mathbf{2 0 1 1 / 2 0 1 2}$ \\
\hline $\mathrm{CaCo}_{3}$ & $\%$ & 1.47 & 1.73 \\
\hline Organic matter & $\%$ & 1.64 & 1.91 \\
\hline Available nitrogen & $\%$ & 0.87 & 0.94 \\
\hline Available phosphorus & $\%$ & 0.41 & 0.43 \\
\hline Available potassium & $\%$ & 0.81 & 0.79 \\
\hline $\mathrm{E}-\mathrm{C}$ & $\mathrm{ds} / \mathrm{m}$ & 1.22 & 1.13 \\
\hline $\mathrm{pH}$ & --------- & 7.53 & 7.42 \\
\hline
\end{tabular}

\section{Fertilization treatments:}

Hippeastrum vittatum plants received chemical fertilizer (using ammonium nitrate $(33 \% \mathrm{~N})$, calcium superphosphate $\left(15.5 \% \mathrm{P}_{2} \mathrm{O}_{5}\right)$ and potassium sulfate $\left(48 \% \mathrm{~K}_{2} \mathrm{O}\right)$. A mixture of the three fertilizers, with a ratio of 2:1:2 ( $\left.\mathrm{N}: \mathrm{P}_{2} \mathrm{O}_{5}: \mathrm{K}_{2} \mathrm{O}\right)$, was prepared and applied to the plants at the rate of 2, 4 and $6 \mathrm{~g} /$ plant $(8,16$ and $24 \mathrm{~g} / \mathrm{plot})$ as side dressing five times at monthly interval, starting 55 days from planting in both seasons.

\section{Kinetin treatments:}

Hippeastrum vittatum plants were subjected to foliar spray with kinetin at the rates of $0,20,40$ and $60 \mathrm{ppm}$ three times, each at one month interval, the first one was after two months from planting time in both seasons. A surfactant (Tween 20 ) at a concentration of $0.01 \%$ was added to all tested solutions including the control. 


\section{Layout of the Experiment:}

The design of this experiment was factorial experiments in a complete randomize block design with 16 treatments represented the combinations between kinetin at the rates of $0,20,40$ and $60 \mathrm{ppm}$ and chemical fertilization at the rates of $0,2,4$ and $6 \mathrm{~g} /$ plants $(4$ chemical fertilization levels $\times 4$ kinetin concentrations) replicated three times (each replicate consisted of five beds, with four bulbs/bed). Common agricultural practices (irrigation, manual weed control,... etc.) were carried out when needed.

\section{Recorded data:}

1- Vegetative growth parameters: weight.

Plant height, number of leaves, leaves fresh weight and leaves dry

\section{2-Flowering growth parameters:}

Flowering start (number of days from planting time to show color of the first flower), inflorescence length, flowering stem diameter and inflorescence fresh weight.

\section{3- Bulb growth parameters:} bulblet.

Bulb diameter, fresh and dry weight of bulb, number and diameter of

\section{4- Leaves chemical composition determinations:}

a- Total nitrogen percentage was determined in the dried leaves by using modified micro-kjeldahl method as described by Pregl (1945).

b- Phosphorus was determined colourimetrically in spectronic (20) spectrophotometer using the method described by Trouge and Meyer (1939).

c- Potassium content was determined by flame photometer according to Brown and Lilleland (1946).

d-Total carbohydrates content was determined in dried leaf powder according to Herbert et al. (1971).

e- Total chlorophylls content was determined in fresh leaf according to A.O.A.C (1990).

All samples of chemical analyses were taken at the flowering start.

\section{5- Endogenous phytohormones:}

Endogenous phytohormones were quantitatively determined in Hippeastrum vittatum leaves just before flowering in the second season using High- Performance Liquid Chromato-graphy (HPLC) according to Koshioka et al. (1983) for auxin (IAA), gibberellins and abscisic acid (ABA), while cytokinins were determined according to Nicander et al. (1993).

\section{6-Anatomical study:}

Leaf samples were taken from the 4th leaf of all treated plants including control plants just before flowering. The specimens were taken then killed and fixed in FAA ( $5 \mathrm{ml}$. formalin, $5 \mathrm{ml}$. glacial acetic acid and $90 \mathrm{ml}$. ethyl alchohol $70 \%$ ), washed in $50 \%$ ethyl alcohol, dehydrated in series of ethyl alchohols $70,90,95$ and $100 \%$, infiltrated in xylene, embedded in paraffin wax with a melting point of 60-63 o C, sectioned to 20 microns in thickness (Sass, 1951), stained with the double stain method (fast green and safranin), cleared in xylene and mounted in Canada balsam (Johanson, 
1940). Sections were read to detect histological manifestation of noticeable responses resulted from other treatments. The prepared sections were microscopically examined; counts and measurements $(\mu)$ were taken using a micrometer eye piece.

Statistical analysis

All data obtained in both seasons of study were subjected to analysis of variance as factorial experiments in a complete randomize block design. L.S.D. method was used to difference means according to Snedecor and Cochran (1989).

\section{RESULTS AND DISCUSSION}

\section{1-Vegetative growth parameters:}

\section{a- Plant height:}

Table (1) shows that all tested concentrations of kinetin succeeded in increasing plant height of Hippeastrum vittatum plants as compared with unsprayed plants in both seasons. In this respect, the low concentration (20 $\mathrm{ppm}$ ) gave the highest values in this concern, followed by the medium concentration $(40 \mathrm{ppm})$ in both seasons. On the other hand, there was a positive correlation between the plant height values and fertilization levels, so the values of plant height increased as the level of fertilization increased until reach to the maximum increasing at the high level $(6 \mathrm{~g} / \mathrm{plant})$. This trend was true in both seasons.

Moreover, data in Table (1) indicate that all the interactions between kinetin concentrations and fertilization levels statistically increased plant height of Hippeastrum plants as compared with untreated plants in both seasons. However, the tallest plants $(41.23$ and $40.23 \mathrm{~cm})$ were recorded by $20 \mathrm{ppm}$ kinetin combined with NPK fertilization at $6 \mathrm{~g} /$ plant treatment in the first and second seasons, respectively.

Table (1): Effect of kinetin and NPK fertilization treatments on plant height and leaves number of Hippeastrum vittatum plants during 2010/2011and 2011/2012 seasons.

\begin{tabular}{|c|c|c|c|c|c|c|c|c|c|c|c|}
\hline \multicolumn{12}{|c|}{ First season $(2010 / 2011)$} \\
\hline \multicolumn{2}{|c|}{\begin{tabular}{|l|} 
Parameters \\
\end{tabular}} & \multicolumn{4}{|c|}{ Plant height $(\mathrm{cm})$} & \multirow[b]{2}{*}{ Mean } & \multicolumn{4}{|c|}{ Leaves number/plant } & \multirow[b]{2}{*}{ Mean } \\
\hline \multicolumn{2}{|c|}{$\begin{array}{lll}\text { Kinetin } & \text { Fertilizer } \\
\end{array}$} & 0.0 & $\begin{array}{c}2 \\
\mathbf{g} / \text { plant }\end{array}$ & $\begin{array}{c}4 \\
\text { g/plant }\end{array}$ & $\begin{array}{c}6 \\
\text { g/plant }\end{array}$ & & 0.0 & \begin{tabular}{|c|}
2 \\
g/plant
\end{tabular} & $\begin{array}{c}4 \\
\text { g/plant }\end{array}$ & $\begin{array}{c}6 \\
\text { g/plant }\end{array}$ & \\
\hline \multicolumn{2}{|c|}{ Kinetin at $0.0 \mathrm{ppm}$} & 32.33 & 34.23 & 36.46 & 37.80 & 35.20 & 8.33 & 9.26 & 9.93 & 10.23 & 9.44 \\
\hline \multicolumn{2}{|c|}{ Kinetin at $20 \mathrm{ppm}$} & 34.16 & 35.73 & 39.36 & 41.23 & 37.62 & 9.63 & 10.36 & 11.26 & 10.93 & 10.55 \\
\hline \multicolumn{2}{|c|}{ Kinetin at $40 \mathrm{ppm}$} & 34.63 & 35.46 & 37.26 & 38.03 & 36.35 & 9.93 & 10.33 & 11.23 & 11.63 & 10.78 \\
\hline \multicolumn{2}{|c|}{ Kinetin at $60 \mathrm{ppm}$} & 34.16 & 37.03 & 36.23 & 37.46 & 36.22 & 10.43 & 11.63 & 11.43 & 12.16 & 11.41 \\
\hline \multicolumn{2}{|c|}{ Mean } & 33.82 & 35.61 & 37.33 & 38.63 & & 9.58 & 10.40 & 10.96 & 11.24 & \\
\hline \multirow{3}{*}{$\begin{array}{l}\text { L.S.D at } \\
0.05 \text { For }\end{array}$} & kinetin & \multicolumn{5}{|c|}{1.85} & \multicolumn{5}{|c|}{0.947} \\
\hline & fertilizer & \multicolumn{5}{|c|}{1.85} & \multicolumn{5}{|c|}{0.947} \\
\hline & interaction & \multicolumn{5}{|c|}{3.70} & \multirow{2}{*}{\multicolumn{5}{|c|}{1.89}} \\
\hline \multicolumn{11}{|c|}{ Second season (2011/2012) } & \\
\hline \multicolumn{2}{|c|}{ Kinetin at $0.0 \mathrm{ppm}$} & 30.90 & 35.13 & 38.33 & 37.90 & 35.56 & 8.93 & 9.60 & 10.13 & 10.66 & 9.83 \\
\hline \multicolumn{2}{|c|}{$\begin{array}{l}\text { Kinetin at } 20 \mathrm{ppm} \\
\text { Kinetin at } 40 \mathrm{ppm}\end{array}$} & 34.86 & 36.23 & 39.83 & 40.23 & 37.79 & 10.00 & 10.50 & 10.63 & 11.16 & 10.57 \\
\hline Kinetin at & & 35.73 & 38.43 & 38.00 & 38.76 & 37.73 & 10.13 & 10.26 & 11.70 & 11.53 & 10.90 \\
\hline \multicolumn{2}{|c|}{ Kinetin at $60 \mathrm{ppm}$} & 35.43 & 36.36 & 37.86 & 38.03 & 36.92 & 10.23 & 11.26 & 12.00 & 12.43 & 11.48 \\
\hline \multicolumn{2}{|c|}{ Mean } & 34.23 & 36.54 & 38.51 & 38.73 & & 9.82 & 10.40 & 11.11 & 11.45 & \\
\hline \multirow{3}{*}{$\begin{array}{l}\text { L.S.D at } \\
0.05 \text { For }\end{array}$} & kinetin & \multirow{2}{*}{\multicolumn{5}{|c|}{$\begin{array}{ll}1.74 \\
1.74\end{array}$}} & \multicolumn{5}{|c|}{0.967} \\
\hline & fertilizer & & & & & & \multicolumn{5}{|c|}{0.967} \\
\hline & interaction & \multicolumn{5}{|c|}{3.47} & \multicolumn{5}{|c|}{1.94} \\
\hline
\end{tabular}




\section{b- Leaves number/ plant:}

Table (1) declares that all tested kinetin and NPK fertilization treatments as well as their interactions increased the number of leaves/plant in both seasons. In this concern, the increment in leaves number were in parallel to applied concentration of kinetin and fertilization levels, so the highest concentration of kinetin or the highest level of fertilization significantly scored the highest number of leaves / plant when compared with control in both seasons. However, the highest number of leaves/plant (12.16 and 12.43) was recorded by $60 \mathrm{ppm}$ kinetin-sprayed plants combined with NPK fertilization at $6 \mathrm{~g} /$ plant in the first and second seasons, respectively.

\section{c- Fresh and dry weights of leaves:}

It was interest to notice that there was a positive relationship between the fresh and dry weights of leaves/plant and kinetin or fertilization treatments. Hence, as the levels of kinetin or fertilization increased the fresh and dry weights of leaves increased up to the maximum increasing at the high level of kinetin or fertilization in both seasons (Table, 2). However, the heaviest fresh and dry weights of leaves/ plant were recorded by $60 \mathrm{ppm}$ kinetin-sprayed plants enriched with NPK fertilization at $6 \mathrm{~g} /$ plant in both seasons.

Table (2): Effect of kinetin and NPK fertilization treatments on fresh and dry weights of leaves/plant of Hippeastrum vittatum plants during 2010/2011and 2011/2012 seasons.

\begin{tabular}{|c|c|c|c|c|c|c|c|c|c|c|c|}
\hline \multicolumn{12}{|c|}{ First season $(2010 / 2011)$} \\
\hline \multicolumn{2}{|c|}{ Parameters } & \multicolumn{4}{|c|}{ Leaves fresh weight (g) } & \multirow[b]{2}{*}{ Mean } & \multicolumn{4}{|c|}{ Leaves dry weight $(\mathrm{g})$} & \multirow[b]{2}{*}{ Mean } \\
\hline \multicolumn{2}{|c|}{$\begin{array}{ll}\text { Kinetin } & \text { Fertilizer } \\
\end{array}$} & 0.0 & $\begin{array}{c}2 \\
\text { g/plant }\end{array}$ & $\begin{array}{c}4 \\
\text { g/plant }\end{array}$ & $\begin{array}{c}6 \\
\text { g/plant }\end{array}$ & & 0.0 & $\begin{array}{c}2 \\
\text { g/plant }\end{array}$ & $\begin{array}{c}4 \\
\mathbf{g} / \text { plant } \\
\end{array}$ & $\begin{array}{c}6 \\
\text { g/plant }\end{array}$ & \\
\hline \multicolumn{2}{|c|}{ Kinetin at $0.0 \mathrm{ppm}$} & 67.2 & 81.6 & 91.8 & 100.0 & 85.1 & 6.05 & 7.76 & 8.82 & 9.65 & 8.07 \\
\hline \multicolumn{2}{|c|}{ Kinetin at $20 \mathrm{ppm}$} & 86.5 & 108.5 & 122.5 & 114.6 & 108.0 & 8.13 & 10.38 & 11.97 & 11.22 & 10.42 \\
\hline \multicolumn{2}{|c|}{ Kinetin at $40 \mathrm{ppm}$} & 103.1 & 110.5 & 123.3 & 129.6 & 116.6 & 9.88 & 10.58 & 12.03 & 12.80 & 11.32 \\
\hline \multicolumn{2}{|c|}{ Kinetin at $60 \mathrm{ppm}$} & 109.9 & 131.9 & 134.9 & 139.3 & 129.0 & 10.85 & 13.03 & 13.43 & 13.92 & 12.80 \\
\hline \multicolumn{2}{|c|}{ Mean } & 91.6 & 108.1 & 118.1 & 120.8 & & 8.72 & 10.43 & 11.56 & 11.89 & \\
\hline \multirow{3}{*}{$\begin{array}{c}\text { L.S.D } \\
\text { at } 0.05 \\
\text { For } \\
\end{array}$} & kinetin & \multicolumn{5}{|c|}{6.15} & \multicolumn{5}{|c|}{0.771} \\
\hline & fertilizer & \multirow{2}{*}{\multicolumn{5}{|c|}{$\frac{6.15}{12.30}$}} & \multicolumn{5}{|c|}{0.771} \\
\hline & interaction & & & & & & & & 1.54 & & \\
\hline \multicolumn{12}{|c|}{ Second season $(2011 / 2012)$} \\
\hline \multicolumn{2}{|c|}{ Kinetin at $0.0 \mathrm{ppm}$} & 73.8 & 87.3 & 95.6 & 108.7 & 91.3 & 7.02 & 8.21 & 9.21 & 10.57 & 8.75 \\
\hline \multicolumn{2}{|c|}{ Kinetin at $20 \mathrm{ppm}$} & 100.9 & 114.5 & 103.2 & 121.0 & 109.9 & 8.04 & 11.10 & 10.71 & 11.97 & 10.45 \\
\hline \multirow{2}{*}{\multicolumn{2}{|c|}{$\begin{array}{l}\text { Kinetin at } 40 \mathrm{ppm} \\
\text { Kinetin at } 60 \mathrm{ppm}\end{array}$}} & 104.3 & 112.6 & 129.5 & 132.7 & 119.8 & 10.11 & 10.81 & 12.70 & 13.07 & 11.67 \\
\hline & Kinetin at $60 \mathrm{ppm}$ & 106.4 & 128.8 & 139.3 & 145.2 & 129.9 & 10.84 & 12.70 & 13.91 & 14.13 & 12.89 \\
\hline \multicolumn{2}{|c|}{ Mean } & 96.3 & 110.8 & 116.9 & 126.8 & & 9.00 & 10.70 & 11.63 & 12.43 & \\
\hline \multirow{3}{*}{$\begin{array}{l}\text { L.S.D } \\
\text { at } 0.05 \\
\text { For }\end{array}$} & kinetin & \multicolumn{5}{|c|}{5.87} & \multicolumn{5}{|c|}{0.765} \\
\hline & fertilizer & \multicolumn{5}{|c|}{5.87} & \multicolumn{5}{|c|}{0.765} \\
\hline & interaction & \multicolumn{5}{|c|}{11.74} & \multicolumn{5}{|c|}{1.53} \\
\hline
\end{tabular}

The obtained results might be due to the role of kinetin on promoting protein synthesis, increasing cell division and enlargement (Cheema and Sharma, 1982). Moreover, these results might be explained according to the role of kinetin on promoting proteins, soluble and non-soluble sugars synthesis, or may be due to the ability of kinetin for making the treated area to act as a sink in which nutrients from other parts of the plant are drawn (Salisbury and Ross, 1974). 
The aforementioned results of kinetin are in conformity with those reported by El-Malt et al. (2006) on Hippeastrum vittatum, Youssef and Ismaeil (2009) on Clivia miniata and Youssef and Mady (2013) on Aspidistra elatior. The abovementioned results of fertilization are in harmony with those attained by Parthiban and Khader (1991) on tuberose plant, Amarjeet and Godara (1995) on Polianthes tuberosa L., Clemens and Morton (1999) on Heliconia plant, Singh et al. (2002) on Gladiolus grandiflorum, Pal and Biswas (2005) on Polianthes tuberosa L., El-Malt et al. (2006) on Hippeastrum vittatum, Youssef and Goma (2007) on Iris tingitana, Abou-ElElla (2007) on Acanthus mollis, El-Naggar and El-Nasharty (2009) on Hippeastrum vittatum and Abd El-All (2011) on Aspidistra elatior.

\section{2- Flowering growth parameters:}

a- Flowering start:

Table (3) illustrates that all tested kinetin and fertilization treatments as well as their interaction induced earlier flowering as compared with untreated control with non-significant differences in both seasons. However, the earlier flowering (178.0 and 180.3 days) was gained by 60 ppm kinetin sprayed plants provided with NPK fertilization at $2 \mathrm{~g} /$ plant, in the first and second seasons, respectively.

Table(3): Effect of kinetin and NPK fertilization treatments on flowering start and flowering stem diameter of Hippeastrum vittatum plants during 2010/2011and 2011/2012 seasons.

\begin{tabular}{|c|c|c|c|c|c|c|c|c|c|c|c|}
\hline \multicolumn{12}{|c|}{ First season (2010/2011) } \\
\hline \multicolumn{2}{|c|}{ Parameters } & \multicolumn{4}{|c|}{ Flowering start (days) } & \multirow{2}{*}{ Mean } & \multicolumn{4}{|c|}{$\begin{array}{l}\text { Flowering stem } \\
\text { diameter }(\mathrm{cm})\end{array}$} & \multirow{2}{*}{ Mean } \\
\hline \multicolumn{2}{|c|}{ Kinetin $\quad$ Fertilizer } & 0.0 & $\begin{array}{c}2 \\
\text { g/plant }\end{array}$ & $\begin{array}{c}4 \\
\text { g/plant }\end{array}$ & $\begin{array}{c}6 \\
\text { g/plant }\end{array}$ & & 0.0 & $\begin{array}{c}2 \\
\mathrm{~g} / \mathrm{plant}\end{array}$ & $\begin{array}{c}\mathbf{4} \\
\text { g/plant }\end{array}$ & $\begin{array}{c}6 \\
\text { g/plant }\end{array}$ & \\
\hline \multicolumn{2}{|c|}{ Kinetin at $0.0 \mathrm{ppm}$} & 189.0 & 184.3 & 186.6 & 187.3 & 186.8 & 1.56 & 1.61 & 1.72 & 1.83 & 1.68 \\
\hline \multicolumn{2}{|c|}{ Kinetin at $20 \mathrm{ppm}$} & 186.3 & 182.0 & 184.3 & 183.3 & 184.0 & 1.64 & 1.68 & 1.74 & 1.78 & 1.71 \\
\hline \multicolumn{2}{|c|}{ Kinetin at $40 \mathrm{ppm}$} & 184.6 & 181.6 & 183.3 & 184.6 & 183.5 & 1.68 & 1.76 & 1.84 & 1.70 & 1.74 \\
\hline \multicolumn{2}{|c|}{ Kinetin at $60 \mathrm{ppm}$} & 182.3 & 178.0 & 180.6 & 181.3 & 180.6 & 1.74 & 1.92 & 1.89 & 1.96 & 1.87 \\
\hline \multicolumn{2}{|c|}{ Mean } & 185.6 & 181.5 & 183.7 & 184.1 & & 1.65 & 1.74 & 1.79 & 1.81 & \\
\hline \multirow{3}{*}{$\begin{array}{l}\text { L.S.D at } \\
0.05 \\
\text { For }\end{array}$} & kinetin & \multicolumn{5}{|c|}{ N.S } & \multicolumn{5}{|c|}{0.118} \\
\hline & fertilizer & \multicolumn{5}{|c|}{ N.S } & \multicolumn{5}{|c|}{0.118} \\
\hline & interaction & \multicolumn{5}{|c|}{ N.S } & \multicolumn{5}{|c|}{0.236} \\
\hline \multicolumn{12}{|c|}{ Second season (2011/2012) } \\
\hline \multicolumn{2}{|c|}{ Kinetin at $0.0 \mathrm{ppm}$} & 193.3 & 187.0 & 189.6 & 188.3 & 189.6 & 1.50 & 1.59 & 1.68 & 1.65 & 1.61 \\
\hline \multicolumn{2}{|c|}{ Kinetin at $20 \mathrm{ppm}$} & 189.0 & 185.6 & 188.0 & 188.3 & 187.7 & 1.61 & 1.71 & 1.68 & 1.74 & 1.68 \\
\hline \multicolumn{2}{|c|}{ Kinetin at $40 \mathrm{ppm}$} & 187.3 & 180.6 & 183.3 & 186.3 & 184.4 & 1.64 & 1.79 & 1.76 & 1.82 & 1.75 \\
\hline \multicolumn{2}{|c|}{ Kinetin at $60 \mathrm{ppm}$} & 185.6 & 180.3 & 182.3 & 183.3 & 182.9 & 1.72 & 1.83 & 1.91 & 1.93 & 1.84 \\
\hline \multicolumn{2}{|c|}{ Mean } & 188.8 & 183.4 & 185.8 & 186.6 & & 1.62 & 1.73 & 1.75 & 1.78 & \\
\hline \multirow{3}{*}{$\begin{array}{l}\text { L.S.D at } \\
0.05 \\
\text { For }\end{array}$} & kinetin & \multicolumn{5}{|c|}{ N.S } & \multicolumn{5}{|c|}{0.095} \\
\hline & fertilizer & \multicolumn{5}{|c|}{ N.S } & \multicolumn{5}{|c|}{0.095} \\
\hline & interaction & \multicolumn{5}{|c|}{ N.S } & \multicolumn{5}{|c|}{0.190} \\
\hline
\end{tabular}

\section{b- Flowering stem diameter:}

Data presented in Table (3) declare that flowering stem diameter increased as the concentration of kinetin increased. Consequently $60 \mathrm{ppm}$ kinetin - sprayed plants recorded the highest values of this parameter in both seasons. Paralley, flowering stem diameter increased with all tested levels of NPK fertilization, especially the high level in both seasons. In 
general, all interaction between kinetin and NPK fertilization treatments succeeded in increasing the diameter of flowering stem as compared with control in the two seasons. However, the highest values of flowering stem diameter $(1.96$ and $1.93 \mathrm{~cm})$ were scored by $60 \mathrm{ppm}$ kinetin-sprayed plants supplemented with NPK fertilization at $6 \mathrm{~g} /$ plant in the first and second seasons, respectively.

\section{c- Length and fresh weight of inflorescence:}

It was found that the length and fresh weight of inflorescence are proportionally increased with the increment of kinetin or NPK fertilization level (Table, 4). Therefore, the high level of kinetin or fertilization significantly recorded the highest values in this respect as compared with untreated plants in both seasons. Generally, all resulted combinations of kinetin and NPK fertilization statistically increased the values of these parameters as compared with control in the two seasons. However, $60 \mathrm{ppm}$ kinetin- sprayed plants joined with NPK fertilization at $6 \mathrm{~g} / \mathrm{plant}$ induced the highest values in this concern.

Table(4):Effect of kinetin and NPK fertilization treatments on inflorescence length and inflorescence fresh weight of Hippeastrum vittatum plants during 2010/2011and 2011/2012 seasons.

\begin{tabular}{|c|c|c|c|c|c|c|c|c|c|c|c|}
\hline \multicolumn{12}{|c|}{ First season (2010/2011) } \\
\hline \multicolumn{2}{|c|}{ Parameters } & \multicolumn{4}{|c|}{ Inflorescence length $(\mathrm{cm})$} & \multirow{2}{*}{ Mean } & \multicolumn{4}{|c|}{$\begin{array}{c}\text { Inflorescence fresh } \\
\text { weight (g) }\end{array}$} & \multirow{2}{*}{ Mean } \\
\hline \multicolumn{2}{|c|}{ Kinetin } & 0.0 & $\begin{array}{c}2 \\
\text { g/plant }\end{array}$ & $\begin{array}{c}4 \\
\text { g/plant }\end{array}$ & $\begin{array}{c}6 \\
\text { g/plant }\end{array}$ & & 0.0 & $\begin{array}{c}2 \\
\mathrm{~g} / \text { plant }\end{array}$ & $\begin{array}{c}4 \\
\text { g/plant }\end{array}$ & $\begin{array}{c}6 \\
\mathrm{~g} / \text { plant }\end{array}$ & \\
\hline \multicolumn{2}{|c|}{ Kinetin at $0.0 \mathrm{ppm}$} & 42.63 & 43.90 & 45.67 & 46.23 & 44.60 & 147.7 & 150.8 & 152.7 & 158.2 & 152.4 \\
\hline \multicolumn{2}{|c|}{ Kinetin at $20 \mathrm{ppm}$} & 45.63 & 49.33 & 51.83 & 54.66 & 50.36 & 152.4 & 158.1 & 162.3 & 161.1 & 158.5 \\
\hline \multicolumn{2}{|c|}{ Kinetin at $40 \mathrm{ppm}$} & 46.96 & 48.23 & 51.43 & 51.90 & 49.63 & 155.7 & 157.8 & 162.2 & 165.4 & 160.3 \\
\hline \multicolumn{2}{|c|}{ Kinetin at $60 \mathrm{ppm}$} & 48.43 & 53.63 & 53.43 & 55.26 & 52.68 & 158.1 & 167.1 & 167.8 & 169.8 & 165.7 \\
\hline \multicolumn{2}{|c|}{ Mean } & 45.91 & 48.77 & 50.59 & 52.01 & & 153.5 & 158.4 & 161.3 & 163.6 & \\
\hline \multirow{3}{*}{$\begin{array}{c}\text { L.S.D } \\
\text { at } \\
0.05 \\
\text { For }\end{array}$} & kinetin & \multicolumn{5}{|c|}{4.86} & \multicolumn{5}{|c|}{7.62} \\
\hline & fertilizer & \multicolumn{5}{|c|}{4.86} & \multicolumn{5}{|c|}{7.62} \\
\hline & interaction & \multicolumn{5}{|c|}{9.73} & \multicolumn{5}{|c|}{15.24} \\
\hline \multicolumn{12}{|c|}{ Second season $(2011 / 2012)$} \\
\hline \multicolumn{2}{|c|}{ Kinetin at $0.0 \mathrm{ppm}$} & 45.73 & 47.10 & 48.90 & \begin{tabular}{l|l}
46.10 \\
\end{tabular} & 46.95 & 151.3 & 153.7 & 157.7 & 158.1 & 155.2 \\
\hline \multicolumn{2}{|c|}{ Kinetin at $20 \mathrm{ppm}$} & 49.66 & 52.80 & 52.46 & 53.13 & 52.01 & 157.7 & 162.7 & 162.7 & 163.3 & 161.6 \\
\hline \multicolumn{2}{|c|}{ Kinetin at $40 \mathrm{ppm}$} & 51.36 & 50.10 & 56.33 & 55.90 & 53.42 & 158.2 & 164.1 & 170.3 & 171.1 & 165.9 \\
\hline \multicolumn{2}{|c|}{ Kinetin at $60 \mathrm{ppm}$} & 49.13 & 54.90 & 56.33 & 57.46 & 54.45 & 160.1 & 169.2 & 172.1 & 173.7 & 168.8 \\
\hline \multicolumn{2}{|c|}{ Mean } & 48.97 & 51.22 & 53.50 & 53.15 & & 156.8 & 162.4 & 165.7 & 166.6 & \\
\hline \multirow{3}{*}{$\begin{array}{c}\text { L.S.D } \\
\text { at } \\
0.05 \\
\text { For }\end{array}$} & kinetin & \multicolumn{5}{|c|}{6.26} & \multicolumn{5}{|c|}{7.90} \\
\hline & fertilizer & \multicolumn{5}{|c|}{6.26} & \multicolumn{5}{|c|}{7.90} \\
\hline & interaction & \multicolumn{5}{|c|}{12.53} & \multicolumn{5}{|c|}{15.80} \\
\hline
\end{tabular}

The obtained results might be due to the role of kinetin on promoting protein synthesis, increasing cell division, enlargement and chlorophyll synthesis (Cheema and Sharma, 1982). Moreover, these results might be explained according to the role of kinetin on promoting proteins, soluble and non-soluble sugars synthesis, or may be due to the ability of kinetin for making the treated area to act as a sink in which nutrients from other parts of the plant are drawn (Salisbury and Ross, 1974). 
The aforementioned results of kinetin are in conformity with those reported by Runkova (1985) on Dhalia pinnata, Auda (1992) on Hippeastrum vittatum, Maximoos (1993) on Gerbera jamesonii, El-Malt et al. (2006) on Hippeastrum vittatum and Youssef and Ismaeil (2009) on Clivia miniata. The abovementioned results of fertilization are in harmony with those attained by Parthiban and Khader (1991) on tuberose plant, Amarjeet and Godara (1995) on Polianthes tuberosa L. plant, Clemens and Morton (1999) on Heliconia plant, Khalafalla et al. (2000) on Ornithogalum thyrosoides, Singh et al. (2002) on Gladiolus grandiflorum, Pal and Biswas (2005) on Polianthes tuberosa L., El-Malt et al. (2006) on Hippeastrum vittatum, Youssef and Goma (2007) on Iris tingitana, Abou-El-Ella (2007) on Acanthus mollis, and El-Naggar and El-Nasharty (2009) on Hippeastrum vittatum.

\section{3- Bulb parameters:}

Table (5) demonstrates that all tested concentration of kinetin significantly increased the diameter, fresh and dry weights of bulb, particularly the medium concentration (40 ppm) as compared with unsprayed plants in the two seasons. Also, it is easy to realize that there was a steadily increments in the values of diameter, fresh and dry weights of bulb with increasing NPK fertilization level, so $6 \mathrm{~g}$-fertilized plants registered the greatest values of these parameters in the two seasons. Briefly, the highest bulb diameter ( 8.48 and $8.37 \mathrm{~cm}$ ), the heaviest bulb fresh weight (199.6 and $197.5)$ and the heaviest bulb dry weight $(36.16$ and $35.63 \mathrm{~g})$ were obtained by $40 \mathrm{ppm}$ kinetin-sprayed plants combined with NPK fertilization at $6 \mathrm{~g} /$ plant as compared by untreated plants in the first and second seasons, respectively.

\section{4-Bulblet parameters:}

Table (6) reveals that the values of number and diameter of bulblets are linearly increased with increasing the levels of kinetin or fertilization treatments, hence the high level of kinetin ( $60 \mathrm{ppm}$ ) or fertilization ( $6 \mathrm{~g} /$ plant) showed to be the most effective ones for producing the highest values in this sphere in both seasons. However, the highest number of bulblets / plant ( 8.31 and 9.21 ) and the greatest bulblet diameter( 4.42 and $4.36 \mathrm{~cm}$ ) were scored by $60 \mathrm{ppm}$ kinetin-sprayed plants enriched with NPK fertilization at $6 \mathrm{~g} /$ plant in the first and second seasons, respectively.

These results might be explained according to the role of kinetin on promoting proteins synthesis, soluble and non-soluble sugars synthesis, or may be due to the ability of kinetin for making the treated area to act as a sink into which nutrients from other parts of the plant are drawn. Additionally, these results may explain the role of cytokinins in promoting proteins and pigments synthesis and their ability to delay senescence and withdraw sugars and other solutes from older parts of a plant to the new organs (Salisbury and Ross, 1974). In the same line, Leopol and Kawase (1964) stated that cytokinins stimulate the movement of sugars, starch, amino acids and many other solutes from mature organs to primary tissues of other ones. Furthermore, may be due to the role of kinetin on increasing the promoters in the plant tissues at the expense of the inhibitors to increase 
roots growth. Moreover, it is well established that cytokinins stimulate lateral roots initiation, absorption and thus increasing the size (number, thickness, fresh and dry weights) (Devlin and Witham, 1983).

The abovementioned results of kinetin are in harmony with those attained by Auda (1992) on Hippeastrum vittatum, Shahin (1998) on Crinum and Hemerocallis plants, El-Malt et al. (2006) on Hippeastrum vittatum and Youssef and Ismaeil (2009) on Clivia miniata. The aforementioned results of fertilization are in conformity with earlier reports of Parthiban and Khader (1991) on tuberose, EL-Naggar (1994) on Gladiolus hybrid, Amarjeet and Godara (1995) on Polianthes tuberosa L., Khalafalla et al. (2000) on Ornithogalum thyrosoides, Singh et al. (2002) on Gladiolus grandiflorum, $\mathrm{Pal}$ and Biswas (2005) on Polianthes tuberosa, El-Malt et al. (2006) on Hippeastrum vittatum, Youssef and Goma (2007) on Iris tingitana and ElNaggar and El-Nasharty (2009) on Hippeastrum vittatum.

\section{5-Chemical constituents:}

a- Leaf $\mathrm{N}, \mathrm{P}$ and $\mathrm{K}$ content:

Table (7) shows that all tested treatments of kinetin, fertilization and their combinations succeeded in increasing leaf $\mathrm{N}, \mathrm{P}$ and $\mathrm{K}$ contents as compared with control in both seasons. However, the highest leaf $\mathrm{N}$ content $(2.74 \%)$ was recorded by $60 \mathrm{ppm}$ kinetin- sprayed plants provided with NPK fertilization at $6 \mathrm{~g} /$ plant in the first season and the combined treatment between $60 \mathrm{ppm}$ kinetin-sprayed plant and NPK fertilization at $4 \mathrm{~g} /$ plant in the second one as it gave $2.84 \%$, whereas the richest leaf $P$ content $(0.312$ and $0.269 \%$ ) was registered by $40 \mathrm{ppm}$ kinetin -sprayed plants combined with NPK fertilization at $6 \mathrm{~g} /$ plant in first and second seasons, respectively. While, the greatest leaf $\mathrm{K}$ content $(3.61 \%)$ was scored in the first season by $20 \mathrm{ppm}$ kinetin-sprayed plants supplemented with NPK fertilization at 6 $\mathrm{g} / \mathrm{plant}$ and by the combined treatment between $60 \mathrm{ppm}$ kinetin-sprayed plants enriched with NPK fertilization at $2 \mathrm{~g} /$ plant as it gave $3.92 \%$ in the second one.

b- Leaf total carbohydrates and total chlorophylls content:

Table (8) indicates that all tested kinetin concentrations increased leaf total carbohydrates and total chlorophylls contents as compared with un-treated plants in both seasons. Also, the increments of leaf total carbohydrates and total chlorophylls contents were in parallel to the increasing of fertilization level to reach the maximum increasing at the high level in both seasons. In general, all resulted interactions between kinetin and fertilization treatments statistically increased the values of these parameters as compared with control in both seasons. However, the highest values of leaf total carbohydrates (14.63 and $14.43 \%$ ) and total chlorophylls (249.6 and $256.0 \mathrm{mg} / 100 \mathrm{~g} \mathrm{F.W}$ ) contents were recorded by 60 ppm kinetinsprayed plants supplemented with NPK fertilization at $6 \mathrm{~g} / \mathrm{plant}$, in the first and second seasons, respectively. 
J. Plant Production, Mansoura Univ., Vol. 5 (3), March, 2014

T5 
Youssef, A.S.M. and M.M.M. Abd El-Aal

t- 6 
J. Plant Production, Mansoura Univ., Vol. 5 (3), March, 2014

t 7 
Youssef, A.S.M. and M.M.M. Abd El-Aal

8

370 
As for the explanation of the incremental effect of kinetin on chemical constituents of Hippeastrum content, it could be illustrated here on the basis that kinetin treatments stimulated the endogenous cytokinins synthesis as will be mentioned afterwards and there is an intimate relationship between cytokinins and chlorophylls metabolism in both excided or detached leaf disks and intact plants i.e., cytokinins retard chlorophylls degradation, preserve it and increase its synthesis (Devlin and Witham, 1983). Besides, cytokinins activate a number of enzymes participating in a wide range of metabolic reactions in the leaves. These reactions included the maturation of proplastid into chloroplasts. These enzymes could be divided into two groups according to their response to cytokinins. The first group of enzymes could be said to relate to chloroplast differentiation, while the second one could be related to cytokinin stimulated group (Kulaeva, 1979). Also, these results may explain the role of cytokinins on promoting proteins and pigments synthesis and their ability to delay senescence and withdraw sugars and other solutes from older parts of a plant to the new organs (Salisbury and Ross, 1974). In the same line Leopol and Kawase (1964) stated that cytokinins stimulate the movement of sugars, starch, amino acids and many other solutes from mature organs to primary tissues of other ones. Furthermore, it may be due to the role of kinetin on increasing the growth promoters in the plant tissues at the expense of the inhibitors. In this concern, Kenneth (1979) reported that total control of plant growth is vested not in a single hormonal type - that of auxin - but is shared by several specially auxins, cytokinins, gibberellins and ethylene and this further subjected to namely the phenols, flavons and absicsic acid. The stimulated effect of fertilization treatments may be due to the role of mineral fertilization on supplying the plants with their required nutrients for more carbohydrates and proteins production which are necessary for vegetative, flowering, bulbs growth and chemical composition of the plants (Marschner, 1997).

The aforementioned results of kinetin are in conformity with those obtained by Maximoos (1993) on Gerbera jamesonii, Shahin (1998) on Crinum and Hemerocallis plants, El-Malt et al. (2006) on Hippeastrum vittatum, Youssef and Ismaeil (2009) on Clivia miniata and Youssef and Mady (2013) on Aspidistra elatior. The abovementioned results of fertilization are in harmony with those attained by Parthiban and Khader (1991) on tuberose plant, EL-Naggar (1994) on Gladiolus hybrid, Amarjeet and Godara (1995) on Polianthes tuberosa L., Clemens and Morton (1999) on Heliconia plant, Khalafalla et al. (2000) on Ornithogalum thyrosoides, Atta-Alla and Zaghloul (2002) on Iris tingitana, Pal and Biswas (2005) on Polianthes tuberosa L., El-Malt et al. (2006) on Hippeastrum vittatum, Youssef and Goma (2007) on Iris tingitana, Abou-El-Ella (2007) on Acanthus mollis, El-Naggar and El-Nasharty (2009) on Hippeastrum vittatum and Abd El-All, (2011) on Aspidistra elatior.

\section{6- Endogenous phytohormones:}

As shown in Table (9) different applied treatments changed endogenous phytohoromones, indole acetic acid (IAA), abscisic acid (ABA), 
gibberellic acids $\left(\mathrm{GA}_{3}\right)$ and cytokinins content of Hippeastrum vittatum leaves as compared with untreated plant.

As for cytokinines, data clearly indicate that the cytokinines level positively responded to the different assigned treatments. It was increased nearly to two times in cases of kinetin and NPK fertilizer combination compared with control treatment. Since, the content was the lowest in case of the control. It is worthy to note that the rate of promotion increased gradually as the rate of kinetin and fertilizer increased up to kinetin at $60 \mathrm{ppm}$ with fertilizer at $6 \mathrm{~g} /$ plant. Furthermore, endogenous auxin highly increased with most kinetin and fertilizer combination compared with control treatment, yet it was decreased with control, whereas the highest leaf auxin content was gained by 20ppm kinetin-sprayed plants combined with fertilizer at $6 \mathrm{~g} / \mathrm{plant}$.

With regard to, the endogenous gibberellin like-substances $\left(\mathrm{GA}_{3}\right)$, nearly the most treatments gave decreasing in leaf $\mathrm{GA}_{3}$ content as compared with control. Yet, the combinations of kinetin at $60 \mathrm{ppm}$ with NPK fertilizer at $2 \mathrm{~g} / \mathrm{plant}$ and individually fertilizer at $6 \mathrm{~g} /$ plant treatments increased the amount of this hormone. In this respect, it is well known that the application of hormones affects the levels of endogenous hormones Etienne et al., (1993) and Ribnicky et al., (1996) which should also be taken into account in the interpretation of their physiological effects.

As for, the growth inhibitor (Abscisic acid), its level was decreased with various assigned treatments compared with the control. Worthy to note that the rate of abscises acid decreased gradually as the rate of kinetin and fertilizer increased up to kinetin at $60 \mathrm{ppm}$ with NPK fertilizer at 4 and $6 \mathrm{~g} / \mathrm{plant}$.

Generally, increments of cytokinins and auxins obtained in the present study could be interpret the obtained results of vegetative growth (Tables,1\&2), flowering growth (Tables,3\&4), bulb productivity (Tables,5\&6) as well as chemical constituents (Tables,7\&8). For example, increasing cytokinins could be in favor of increasing the number of formed leaves and bulblets as well as their fresh and dry weights. Whereas, increasing gibberellins and auxins could be in favor of increasing inflorescence length and plant height.

The abovementioned results are of great interest, since the increment of endogenous cytokinins that clearly could be explained the improvement of all growth characteristics obtained in the present study. Since, cytokinins is known as shooting hormones (Salisbury and Ross, 1974) e.g. number of leaves and bulblets were significantly increased as well as the significant increase in leaves fresh and dry weights. Also, of interest is to note that these treatments was accompanied with significant increase in plant height and inflorescence length that is being more expectable when related with the obtained increasing in endogenous auxin levels. Besides, of interest the conclusion that such treatment ornamentally is being of economic value. Since more marketable characteristics of making this plant as an attractive flowering plant were achieved. The abovementioned results have been previously recommended. Since, other studies reported the increase of endogenous cytokinins and auxins as well as reduction of endogenous $A B A$ at the same time. Of these studies are Youssef (2004) Strelitzia reginae and Youssef and Mady (2013) on Aspidistra elatior.

\section{7-Histological study:}

Microscopically counts and measurements of certain histological characteristics in transverse sections through the blade of Hipeastrum vitattum plants as shown in Tables (10, 11 and 12) and Figs. (1\&2) clearly 
indicate that different applied treatments highly affected the anatomical features of the leaf. In this respect, the obtained results indicate that most of the studied features of leaf anatomy were altered with different applied treatments, i.e., kinetin and NPK fertilization as well as their combination compared with untreated treatment. Among these anatomical features were the most important ones, i.e., thickness of blade, length \& width of vascular bundle, phloem \& xylem tissues and number of xylem vessels in vascular bundle.

With regard to the blade thickness, it was increased with different used treatments to reach its maximum value $(4075 \mu)$ with kinetin at $60 \mathrm{ppm}$ enriched with NPK fertilizer at $4 \mathrm{~g} / \mathrm{plant},(3924 \mu)$ with kinetin at $60 \mathrm{ppm}$ supplemented with fertilizer at $6 \mathrm{~g} / \mathrm{plant}$ and $(3709 \mu)$ with kinetin at $60 \mathrm{ppm}$ provided with NPK fertilizer at $2 \mathrm{~g} /$ plant treatment against the control value $(2352 \mu)$. Also the thickness of each of upper and lower epidermis were also increased with most applied treatments. Worthy to note that the rate of promotion gradually enhanced as the rate of kinetin and NPK fertilizer increased up to kinetin at $60 \mathrm{ppm}$ and fertilizer at $6 \mathrm{~g} / \mathrm{plant}$.

Besides, it could be noticed that increment in the blade thickness with different applied treatments attributed to the increase in many of its histological features such as thickness of both upper and lower epidermis tissues, thickness of spongy tissue dimensions of the vascular bundle as well as thickness of phloem tissue, xylem tissue and also number and diameter of xylem vessels in the vascular bundle. For mesophyll tissue, thickness of spongy tissue was increased with different applied treatments. Here, spongy tissue thickness was $2061 \mu$ in the control but increased to reach 3614,3412 and 3308 micron with kinetin at 60 ppm combined with NPK fertilizer at $4 \mathrm{~g} /$ plant, kinetin at $60 \mathrm{ppm}$ enriched with NPK fertilizer at $6 \mathrm{~g} /$ plant and kinetin at $60 \mathrm{ppm}$ joined with NPK fertilizer at $2 \mathrm{~g} / \mathrm{plant}$ treatments, respectively, which were the more effective treatments in the same order.

It is interest, to note that mesophyll increase belongs to that increase of spongy tissue thickness. Since, the spongy tissue was increased with all applied treatments but reached its maximum as other traits with kinetin at 60 ppm supplemented with NPK fertilizer at $4 \mathrm{~g} /$ plant. In this respect, cytokinins known and will recommended to increase the extension growth of plant tissue Devlin and Witham, (1983). This may increase the proportion of protoplasm to cell wall with the result of increased cell size Marschner, (1997).

Furthermore, increasing of vascular tissues is being of great interest, because that could reverse upon improvement of translocation for nutrients and the photosynthates as well. In other meaning translocation of water and different nutrients from soil to leaves from one side and photosynthates from leaves to various plant parts from the other. In addition the above mentioned results are being more evident when thickness of xylem vessels are considered. Also, width of the largest xylem vessel was proportional to the width of stem diameter. 
Youssef, A.S.M. and M.M.M. Abd El-Aal

t9- 10 
J. Plant Production, Mansoura Univ., Vol. 5 (3), March, 2014

-11-t 12 


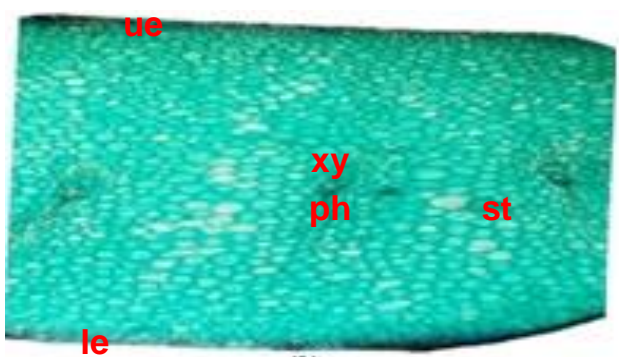

(1)

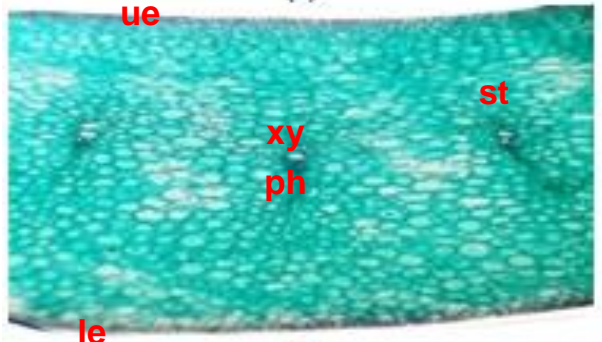

(3

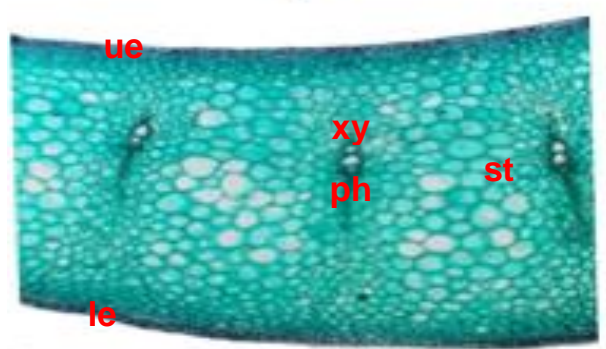

(5)

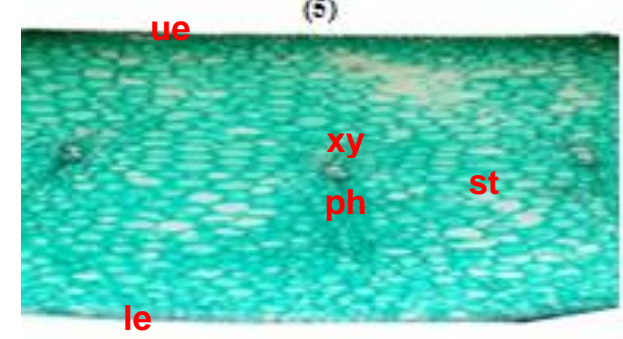

(7)

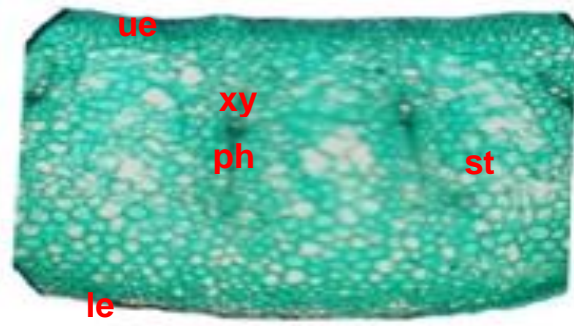

(2)

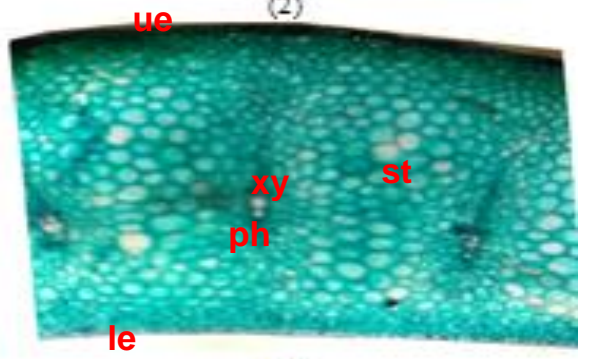

(4)

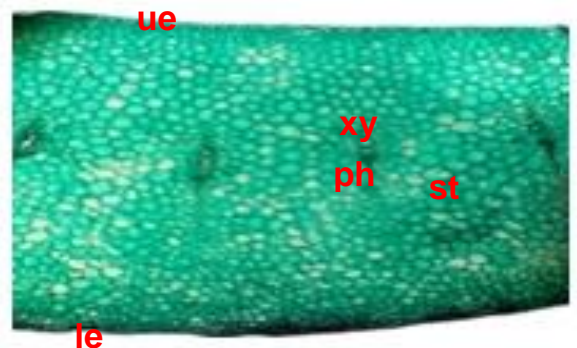

(6)

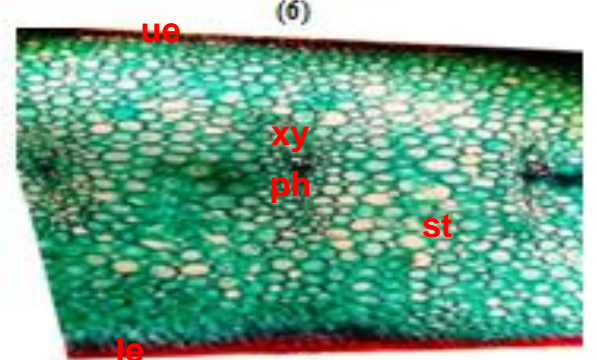

(8) I

Fig. (1): Transverse sections $(X=30)$ through the leaf of Hippeastrum vittatum plants at 2011/2012 season as affected by different applied treatments. Where: (1): control (2): fertilizer at $2 \mathrm{~g} / \mathrm{plant}$ (3): fertilizer at $4 \mathrm{~g} / \mathrm{plant}(4)$ : fertilizer at $6 \mathrm{~g} / \mathrm{plant}(5)$ : kinetin at $20 \mathrm{ppm}$ (6): kinetin at $40 \mathrm{ppm}$ (7): kinetin at $60 \mathrm{ppm}$ and (8): kinetin at $20 \mathrm{ppm}$ with fertilizer at $2 \mathrm{~g} / \mathrm{plant}$. 


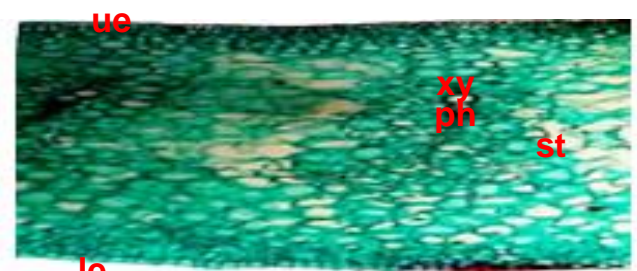

(9)

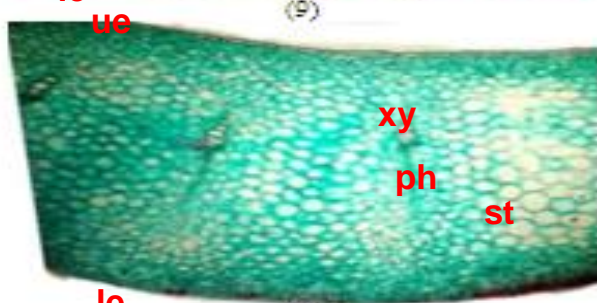

(11)

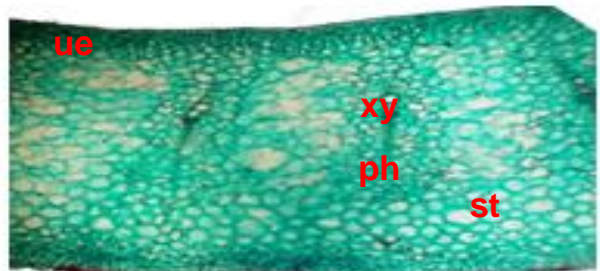

le

(13)

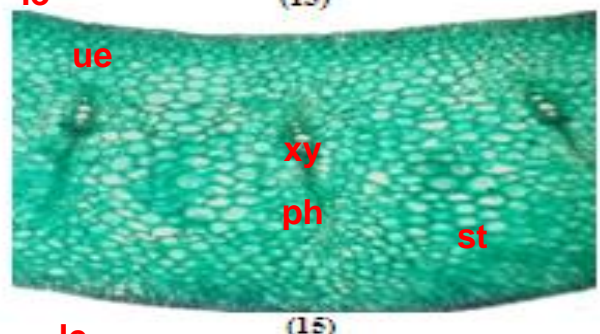

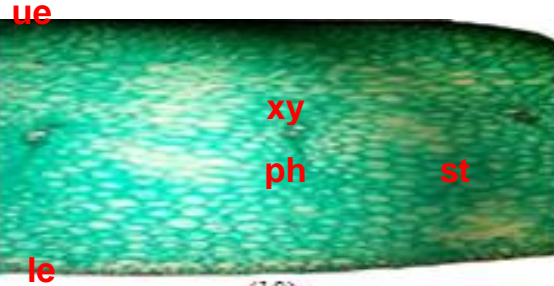

(10)

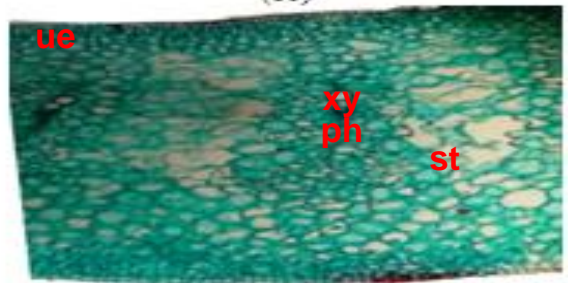

(12)

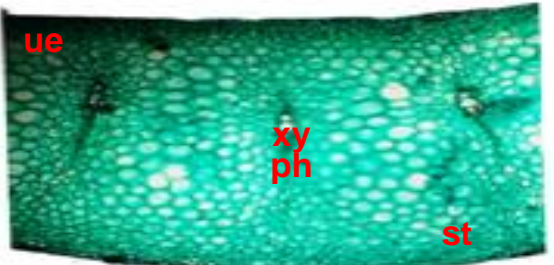

le

(14)

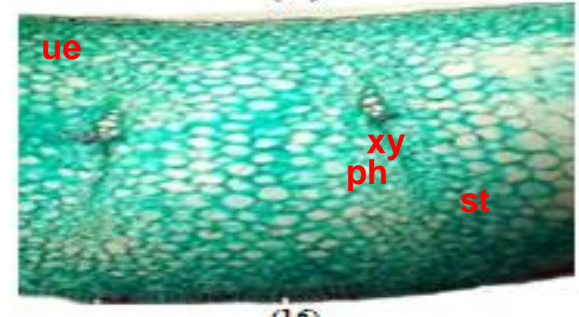

Fig. (2):Transverse sections $(X=30)$ throughe the leaf of Hippeastrum vittatum plants at 2011/2012 season as affected by different applied treatments. Where: (9): kinetin at $20 \mathrm{ppm}$ with fertilizer at $4 \mathrm{~g} / \mathrm{plant}$ (10): kinetin at $20 \mathrm{ppm}$ with fertilizer at $6 \mathrm{~g} / \mathrm{plant}$ (11): kinetin at $40 \mathrm{ppm}$ with fertilizer at $2 \mathrm{~g} /$ plant (12): kinetin at $40 \mathrm{ppm}$ with fertilizer at $4 \mathrm{~g} / \mathrm{plant}(13)$ : kinetin at $40 \mathrm{ppm}$ with fertilizer at $6 \mathrm{~g} / \mathrm{plant}$ (14): kinetin at $60 \mathrm{ppm}$ with fertilizer at $2 \mathrm{~g} /$ plant (15): kinetin at $60 \mathrm{ppm}$ with fertilizer at $4 \mathrm{~g} / \mathrm{plant}$ and (16): kinetin at $60 \mathrm{ppm}$ with fertilizer at $6 \mathrm{~g} / \mathrm{plant}$ ( $\mathrm{ue}=$ Upper epidermis $\mathrm{st}=$ Spongy tissue $\mathrm{xy}=\mathrm{Xylem}$ tissue $\mathrm{ph}=$ phloem tissue le= Lower epidermis). In general, the effects of the applied treatments upon the anatomy features of treated plants especially, in cases of kinetin and fertilizer combination compared with untreated and individually treatment could be attributed to increase of endogenous hormones level, especially cytokinin and auxin as shown in Table (9). These results go on line with that obtained by Youssef and Ismaeil (2007) on Clivia miniata. 
Conclusively, in order to produce good quality Hippeastrum vittatum plants with more bulblets, it is preferable to spray the plants with kinetin at $60 \mathrm{ppm}$ three times supplemented with mineral fertilization at $6 \mathrm{~g} / \mathrm{plant}$ five times a year.

\section{REFERENCES}

A.O.A.C. (1990): Official Methods of Analysis of Association of Official Analytical Chemists. Pub. A.O.A.C. INC. Suite 400, 22201 USA Fifteenth Ed. 1990; pp: 62-63, 236 and 877-878.

Abd El-All, S.G. (2011): Response of cast-iron plant (Aspidistra elatior Blume) to foliar nutrition with greenzit and $\mathrm{GA}_{3}$. M.Sc. Thesis, Fac. Agric., Benha Univ.

Abou El-Ella, E.M. (2007): Physiological studies on Acanthus mollis plant. M.Sc., Thesis, Hort. Dept. Fac. Agric., Benha Univ.

Amarjeet, S. and N.R. Godara (1995): Studies on the nutritional requirement of tuberose (Polianthes tuberosa L.) cv. Single during growth. Haryana Agric. Univ. J. Res., 25(4): 171-174.

Atta-Alla, H.K. and M. Zaghloul (2002): Effect of cold storage, $\mathrm{GA}_{3}$ and fertilization on the growth, flowering and chemical composition of Iris tingitana cv. Wedgwood. J. Agric. Sci. Mansoura Univ., 27 (9): 62676285.

Auda, M.S. (1992): Physiological studies on Amaryllis bulbs. Ph.D. Thesis, Fac. Agric., Ain Shams Univ. Egypt.

Brown, J.D. and O. Lilleland (1946): Rapid determination of potassium and sodium in plant material and soil extract by flame photometry. Proc. Amer. Soc., Hort., Sci., 48:341-346.

Cheema, G.S. and D.P. Sharma (1982): In vitro propagation of apple rootstocks. Int. Hort. Congr XXI. Hamburg, German Federal Republic, Int. Soc. Hort. Sci. Vol. 1: 1035 (Chem. Abst., 52: 7692).

Clemens, J. and R.H. Morton (1999): Optimizing mineral nutrition for flower production in Heliconia Golden Torch' using response surface methodology. J. Amer. Soc. Hort. Sci., 124(6): 713-718.

Devlin, M. and H.Witham (1983): Plant Physiology, 4th Ed. Publishers Willard, Grant Press, Boston.

El-Malt, A.A.T.; E.E. El-Maadawy; M.A. El-Khateeb and Z.H. El-Sadak (2006): Physiological studies on Hippeastrum vittatum L. plants.2Effect of NPK, CCC and BA on growth, bulblet production and flowering. Egypt.J. of Appl. Sci., (6B): 724-742.

El-Naggar, A.H. and A.B. El-Nasharty (2009): Effect of growing media and mineral fertilization on growth, flowering, bulbs productivity and chemical constituents of Hippeastrum vittatum, Herb. AmericanEurasian J. Agric. \& Environ. Sci., 6 (3): 360-371.

El-Naggar, A.H.M. (1994): Effect of different ratios and levels of some fertilizer on the vegetative growth, flowering and corms production of gladiolus. M.Sc. Thesis, Alex. Univ., Egypt. 
Etienne, H. B.; P. Sotta; E. Montoro, C. Miginia and M. P. Car- ron (1993): Relations between exogenous growth regulators and endogenous indole-3-acetic acid and abscisic acid in the expression of somatic embryogenesis in Hevea brasiliensis (Mull. Arg.). Plant Sci. 88, 91-96.

Everett, T.H. (1991): The New York Botanical Garden Illustrated Encyclopedia of Horticulture. Garland Publishing, Inc. New York \& London.

Herbert, D.; P.J. Phipps and R.E. Strange (1971): Determination of total carbohydrates, Methods in Microbiology, 5 (8): 290-344.

Johanson, D. A. (1940): Plant Microtechnique (5th edition) MC. Grow Hill, Book, Company. New York, London. 213- 236.

Kenneth, V.T. (1979): Physiology of Plant Growth and Development. Nalcolm. B. Wilkins TATA McGraw-Hill Publishing Co. Ltd. New-Delhi.

Khalafalla, M.; E. Mahrouk; E. Nofal; A. Nabih and S.Goma (2000): Effect of growing medium and chemical fertilization on growth, flowering, bulb productivity and chemical constituents of Ornithogalum thyrosoides Jacq. Hort. Dept. Agric. Fac. Tanta Univ. Hort. Res. Inst. Agric. Res. Center. Egypt.

Koshioka, M.; J. Harda; M. Noma; T. Sassa; K. Ogiama; J. S. Taylor; S. B. Rood; R. L. Legge and R. P. Pharis (1983): Reversed - phase C18 high performance liquid chromatography of acidic and conjugated gibbberellins. J. Chromatgr., 256:101-115.

Kulaeva, O.N. (1979):Cytokinin action on enzyme activities in plants. In plant growth substances. (Ed.) F. Skoog, Springer-verlage Berlin, Heidelberg. New York (1980), pp. 119-128.

Leopol, A.C. and M. Kawase (1964): Senescence of a trifoliate bean leaf caused by treating the primary leaves of cuttings with benzyladenine. Amer. J. Bot., 51: 294-298.

Marschner, H. (1997): Mineral Nutrition of Higher plants. Second Printing, Academic press INC. San Diego, pp: 889.

Maximoos, S.L. (1993): Physiological and hormonal studies on the growth and flowering of Gerbera Plant. Ph.D. Thesis, Fac. Agric., Ain Shams Univ.

Nicander, B. U. Stahl; P. Bjorkman and E. Tillberg (1993): Immyno affinity copurification of cytokinins and analysis by high-performance liquid chromatography with ultra violet spectrum deterction . planta, 189: 312-320.

Pal, A.K. and B. Biswas (2005): Response of fertilizer on growth and yield of tuberose (Polianthes tuberosa L.) cv. Calacutta Single in the plains of Wast Bengle. J. Interacademicia, Nadia, India, 9(1): 33-36.

Parthiban, S. and M.A. Khader (1991): Effect of NP and K on yield components and yield in tuberose. South Indian Horti., 39(6): 363367.

Pregl, F. (1945): Quantitative organic micro analysis. 4th ED. J. \& Achurnil, London. Regul., 4: 111-122.

Rees, A.R. (1992): Ornamental bulbs, Corms and Tubers. C.A.B. Inter., Wallingford, UK. 61-65. 
Ribnicky, D.M.; N.I. lie; J.C. Cohen and T.J. Cooke (1996): The effects of exogenous auxins on endogenous indole-3-acetic acid metabolism: the implications for carrot somatic enbryogenesis. Plant Physiol. 112, 549-558

Runkova, L.V. (1985): Cytokinin's effect on some ornamental plants. ActaHorticulturae. 1985, No. 167, 69-77; 12 ref.

Salisbury, F.B. and C.W. Ross (1974): Plant Physiology. Publishing Inc. Belmont. California, $2^{\text {nd }}$ ed., pp. 422.

Sass, J. E. (1951): Botanical Microtechnique. lowa State College Press, Ames, lowa, pp.228.

Shahin, S.M.E. (1998):Physiological studies on Crinum and Hemerocallis bulbs. Ph.D. Thesis, Fac. Agric., Tanta Univ.

Singh,W.; S.K. Sehrawat; D.S. Dahiya and K. Singh (2002): Leaf nutrient status of gladiolus (Gladiolus grandiflorus L.) Cv. Sylvia as affected by NPK application. Haryana Journal of Horticultural Sciences, Horticultural Society of Haryana, Hisar, India, 31(1/2): 49-51.

Snedecor, G.W. and W.G. Cochran (1989): Statistical methods. $7^{\text {th }}$ Ed. lowa State Univ. Press. Ames lowa, USA.

Trouge, E. and A.H. Meyer (1939): Improvement in deiness calorimetric for phosphorus and arsenic. Ind. Eng. Chem. Anal. Ed., 1; 136-139.

Youssef, A.S.M. (2004): Physiological studies on growth and flowering of Strelitzia reginae Ait. Plant. Ph.D. Thesis, Fac. of Agric., Moshtohor, Zag. Univ.

Youssef, A.S.M. and A.O. Gomaa (2007): Effect of some horticultural treatments on growth, flowering, bulb production and chemical composition of Iris tingitana cv. Wedgwood. The Third Conf. of Sustain. Agric. and Develop. Fac. of Agric., Fayoum Univ., 12-14 Nov.

Youssef, A.S.M and F.H.M. Ismaeil (2009): Response of Clivia miniata plant to light intensity and kinetin treatments. Annals of Agric. Sc., Moshtohor, Vol. 47(1): Ho. 149-164.

Youssef, A.S.M. and M.A. Mady (2013): Influence of light intensity and benzyladenine on growth performance of Aspidistra elatior Blume plant. Research Journal of Agriculture and Biological Sciences, 9(5): 248-257. 
تـأثير الكيتتين والتسـميد المعدني علـي نمـو وإزهـار وانتاجية الأبصـال والمحتوي

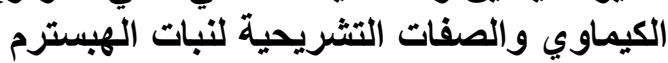

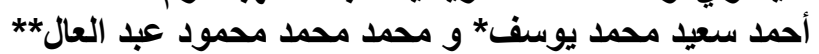

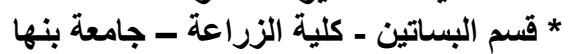

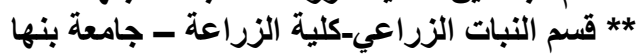

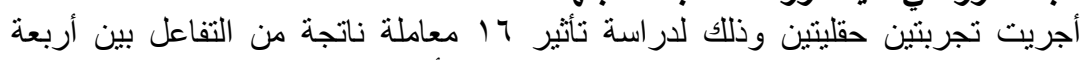

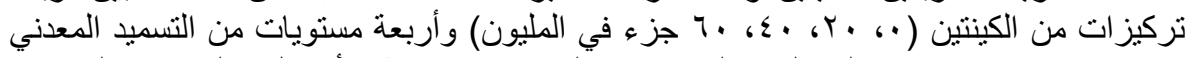

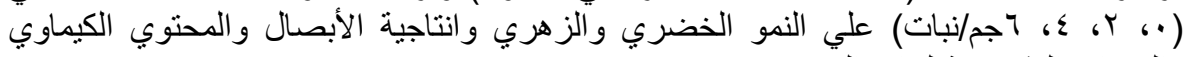
والصفات التشريحية لنبات الهبسترم.

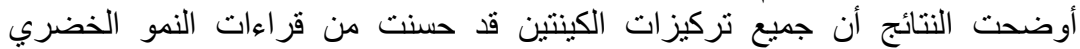

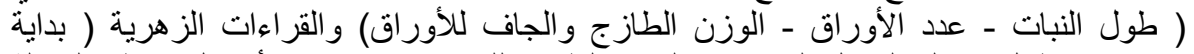

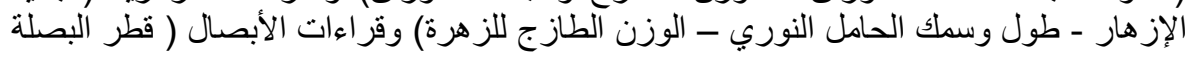

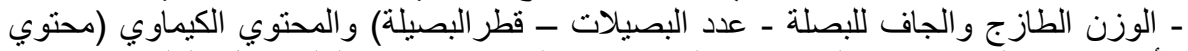

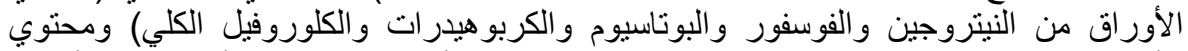

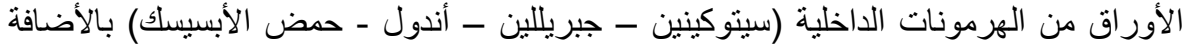

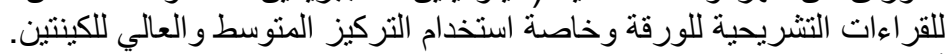

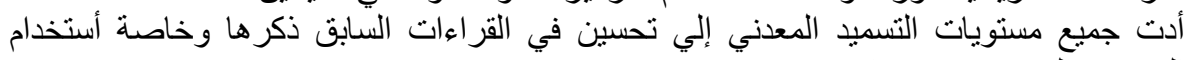
المستوي المرتفع († جم/نبات).

وجد أن معظم التفاعلات بين تركيزات الكيات الكينتين ومستويات التسميد المعدني أدت إلي زيادة

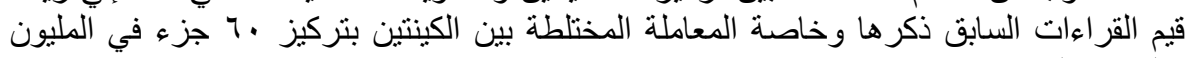

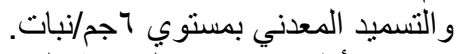

أظهرت نتائج الذراسة التنشريحية للورقة زيادة في معظم قياسات تركيب الورقة نتيجة

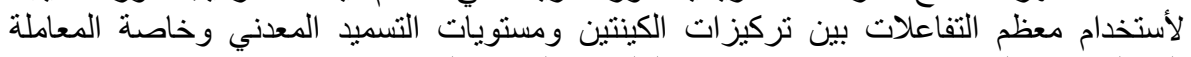

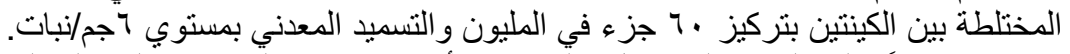

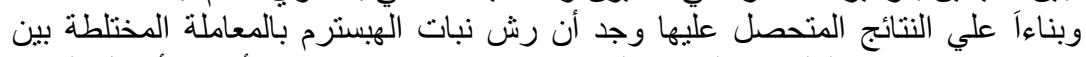

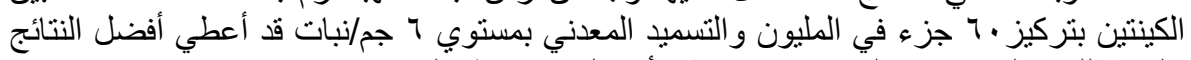
بالنسبة للنمو الخضري و الزهرى والنتاجية الأبصال في معظم الحالات.

كلية الزراعة - جامعة المنصورة كلية الزراعة - جامعة بنها

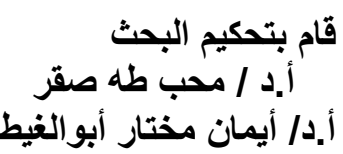


Youssef, A.S.M. and M.M.M. Abd EI-Aal 
J. Plant Production, Mansoura Univ., Vol. 5 (3): 357 - 381 , 2014

Table(5):Effect of kinetin and NPK fertilization treatments on diameter, fresh and dry weights of bulb of Hippeastrum vittatum plants during 2010/2011and 2011/2012 seasons.

\begin{tabular}{|c|c|c|c|c|c|c|c|c|c|c|c|c|c|c|c|c|}
\hline \multicolumn{17}{|c|}{ First season $(2010 / 2011)$} \\
\hline \multicolumn{2}{|c|}{ Parameters } & \multicolumn{4}{|c|}{ Bulb diameter $(\mathbf{c m})$} & \multirow[b]{2}{*}{ Mean } & \multicolumn{4}{|c|}{ Bulb fresh weight $(\mathrm{g})$} & \multirow[b]{2}{*}{ Mean } & \multicolumn{4}{|c|}{ Bulb dry weight (g) } & \multirow[b]{2}{*}{ Mean } \\
\hline \multicolumn{2}{|c|}{ Kinetin $\quad$ Fertilizer } & 0.0 & $2 \mathrm{~g}$ & $\mathbf{4 g}$ & $6 \mathrm{~g}$ & & 0.0 & 2g & $\mathbf{4 g}$ & $6 \mathrm{~g}$ & & 0.0 & $2 \mathrm{~g}$ & $4 \mathrm{~g}$ & $6 \mathrm{~g}$ & \\
\hline \multicolumn{2}{|c|}{ Kinetin at $0.0 \mathrm{ppm}$} & 7.27 & 7.38 & 7.46 & 7.49 & 7.40 & 152.4 & 163.3 & 167.8 & 171.2 & 163.7 & 24.93 & 27.63 & 28.23 & 29.16 & 27.49 \\
\hline \multicolumn{2}{|c|}{ Kinetin at $20 \mathrm{ppm}$} & 7.42 & 7.94 & 8.18 & 8.12 & 7.91 & 166.9 & 178.6 & 189.1 & 190.2 & 181.2 & 28.43 & 30.53 & 32.53 & 33.16 & 31.16 \\
\hline \multicolumn{2}{|c|}{ Kinetin at $40 \mathrm{ppm}$} & 8.14 & 8.36 & 8.43 & 8.48 & 8.35 & 191.2 & 195.6 & 198.2 & 199.6 & 196.1 & 32.70 & 34.80 & 35.43 & 36.16 & 34.77 \\
\hline \multicolumn{2}{|c|}{ Kinetin at $60 \mathrm{ppm}$} & 8.03 & 8.19 & 8.38 & 8.36 & 8.24 & 182.4 & 185.9 & 192.4 & 193.2 & 188.4 & 31.50 & 32.43 & 33.80 & 34.13 & 32.96 \\
\hline \multicolumn{2}{|c|}{ Mean } & 7.71 & 7.96 & 8.11 & 8.11 & & 173.2 & 180.8 & 186.9 & 188.5 & & 29.39 & 31.35 & 32.50 & 33.15 & \\
\hline \multirow{3}{*}{$\begin{array}{l}\text { L.S.D at } \\
0.05 \text { For }\end{array}$} & kinetin & \multirow{2}{*}{\multicolumn{5}{|c|}{0.276}} & \multicolumn{5}{|c|}{8.19} & \multicolumn{5}{|c|}{1.88} \\
\hline & fertilizer & & & & & & \multicolumn{5}{|c|}{8.19} & \multicolumn{5}{|c|}{1.88} \\
\hline & interaction & \multicolumn{5}{|c|}{$\begin{array}{l}0.276 \\
0.553\end{array}$} & \multicolumn{5}{|c|}{16.39} & \multicolumn{5}{|c|}{3.77} \\
\hline \multicolumn{17}{|c|}{ Second season (2011/2012) } \\
\hline \multicolumn{2}{|c|}{ Kinetin at $0.0 \mathrm{ppm}$} & 7.14 & 7.32 & 7.46 & 7.43 & 7.33 & 157.1 & 163.4 & 169.3 & 167.1 & 164.2 & 26.56 & 26.96 & 28.63 & 28.33 & 27.62 \\
\hline \multicolumn{2}{|c|}{ Kinetin at $20 \mathrm{ppm}$} & 7.38 & 7.86 & 7.94 & 8.09 & 7.81 & 164.8 & 176.1 & 182.2 & 182.6 & 176.4 & 27.60 & 29.96 & 31.13 & 31.23 & 29.98 \\
\hline \multirow{2}{*}{\multicolumn{2}{|c|}{$\begin{array}{l}\text { Kinetin at } 40 \mathrm{ppm} \\
\text { Kinetin at } 60 \mathrm{ppm}\end{array}$}} & 7.93 & 8.29 & 8.23 & 8.37 & 8.20 & 181.2 & 192.3 & 193.4 & 197.5 & 191.1 & 30.80 & 33.73 & 34.23 & 35.63 & 33.60 \\
\hline & & 7.90 & 8.07 & 8.19 & 8.26 & 8.10 & 178.9 & 184.1 & 187.3 & 191.7 & 185.5 & 30.63 & 31.90 & 33.30 & 33.86 & 32.42 \\
\hline \multicolumn{2}{|c|}{ Mean } & 7.58 & 7.88 & 7.95 & 8.03 & & 170.5 & 179.0 & 183.0 & 184.7 & & 28.90 & 30.64 & 31.82 & 32.26 & \\
\hline \multirow{3}{*}{$\begin{array}{l}\text { L.S.D at } \\
0.05 \text { For }\end{array}$} & kinetin & \multicolumn{5}{|c|}{0.202} & & & 9.84 & & & & & 1.03 & & \\
\hline & fertilizer & & & 0.202 & & & & & 9.84 & & & & & 1.03 & & \\
\hline & interaction & & & 0.405 & & & & & 19.68 & & & & & 2.06 & & \\
\hline
\end{tabular}


Youssef, A.S.M. and M.M.M. Abd El-Aal

Table (6): Effect of kinetin and fertilization treatments on number and diameter of bulblets of Hippeastrum vittatum plants during 2010/2011and 2011/2012 seasons.

\begin{tabular}{|c|c|c|c|c|c|c|c|c|c|c|c|}
\hline \multicolumn{12}{|c|}{$\begin{array}{ll}\text { First season }(2010 / 2011) \\
\end{array}$} \\
\hline \multirow{2}{*}{\multicolumn{2}{|c|}{$\begin{array}{l}\text { Parameters } \\
\quad \text { Fertilizer }\end{array}$}} & \multicolumn{4}{|c|}{ Bulblets number/plant } & \multirow[b]{2}{*}{ Mean } & \multicolumn{4}{|c|}{ Bulblet diameter (cm) } & \multirow[b]{2}{*}{ Mean } \\
\hline & & 0.0 & $\begin{array}{c}2 \\
\text { g/plant }\end{array}$ & $\begin{array}{c}4 \\
\text { g/plant }\end{array}$ & $\begin{array}{c}6 \\
\text { g/plant }\end{array}$ & & 0.0 & $\begin{array}{c}2 \\
\text { g/plant }\end{array}$ & $\begin{array}{c}4 \\
\text { g/plant }\end{array}$ & $\begin{array}{c}6 \\
\text { g/plant }\end{array}$ & \\
\hline \multicolumn{2}{|c|}{ Kinetin at $0.0 \mathrm{ppm}$} & 4.26 & 4.83 & 4.98 & 5.11 & 4.79 & 2.64 & 2.93 & 3.24 & 3.21 & 3.00 \\
\hline \multicolumn{2}{|c|}{ Kinetin at $20 \mathrm{ppm}$} & 4.93 & 5.49 & 5.46 & 5.62 & 5.37 & 2.98 & 3.19 & 3.49 & 3.52 & 3.29 \\
\hline \multicolumn{2}{|c|}{ Kinetin at $40 \mathrm{ppm}$} & 5.43 & 6.73 & 7.29 & 7.81 & 6.81 & 3.15 & 3.84 & 3.97 & 4.12 & 3.77 \\
\hline \multicolumn{2}{|c|}{ Kinetin at $60 \mathrm{ppm}$} & 6.72 & 7.96 & 7.91 & 8.31 & 7.73 & 4.02 & 4.39 & 4.34 & 4.42 & 4.29 \\
\hline & & 5.33 & 6.25 & 6.41 & 6.71 & & 3.19 & 3.58 & 3.76 & 3.81 & \\
\hline \multirow{3}{*}{$\begin{array}{l}\text { L.S.D at } \\
0.05 \text { For }\end{array}$} & kinetin & \multicolumn{5}{|c|}{0.098} & \multicolumn{5}{|c|}{0.329} \\
\hline & fertilizer & \multirow{2}{*}{\multicolumn{5}{|c|}{$\begin{array}{l}0.098 \\
0.197\end{array}$}} & \multicolumn{5}{|c|}{0.329} \\
\hline & interaction & & & & & & & & 0.658 & & \\
\hline \multicolumn{12}{|c|}{ Second season (2011/2012) } \\
\hline \multicolumn{2}{|c|}{ Kinetin at $0.0 \mathrm{ppm}$} & 4.78 & 4.96 & 5.23 & 5.21 & 5.04 & 2.41 & 2.98 & 2.96 & 3.14 & 2.87 \\
\hline \multirow{2}{*}{\multicolumn{2}{|c|}{$\begin{array}{l}\text { Kinetin at } 20 \mathrm{ppm} \\
\text { Kinetin at } 40 \mathrm{ppm}\end{array}$}} & 5.18 & 5.62 & 5.97 & 6.13 & 5.72 & 2.92 & 3.18 & 3.42 & 3.39 & 3.22 \\
\hline & & 5.90 & 6.68 & 7.50 & 8.03 & 7.04 & 3.07 & 3.62 & 4.03 & 3.96 & 3.67 \\
\hline \multicolumn{2}{|c|}{ Kinetin at $60 \mathrm{ppm}$} & 6.92 & 7.84 & 8.93 & 9.21 & 8.22 & 3.87 & 2.94 & 4.31 & 4.36 & 3.87 \\
\hline \multirow{4}{*}{$\begin{array}{l}\text { L.S.D at } \\
0.05 \text { For }\end{array}$} & an & 5.71 & 6.27 & 6.91 & 7.14 & & 3.06 & 3.18 & 3.68 & 3.71 & \\
\hline & kinetin & \multicolumn{5}{|c|}{0.087} & \multicolumn{5}{|c|}{0.325} \\
\hline & fertilizer & \multirow{2}{*}{\multicolumn{5}{|c|}{$\begin{array}{l}0.087 \\
0.174\end{array}$}} & \multirow{2}{*}{\multicolumn{5}{|c|}{$\begin{array}{l}0.325 \\
0.650\end{array}$}} \\
\hline & interaction & & & & & & & & & & \\
\hline
\end{tabular}


J. Plant Production, Mansoura Univ., Vol. 5 (3), March, 2014

Table (7): Effect of kinetin and NPK fertilization treatments on leaves N, P and K contents of Hippeastrum vittatum plants during 2010/2011and 2011/2012 seasons.

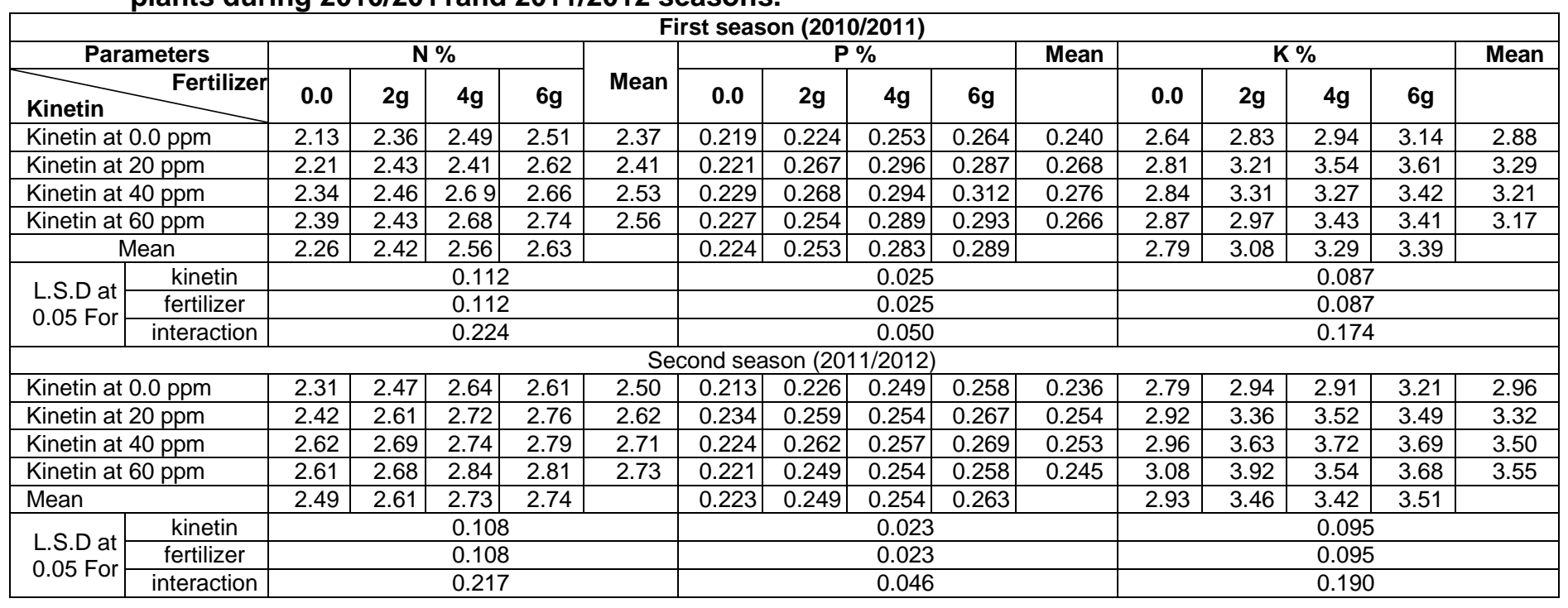


Youssef, A.S.M. and M.M.M. Abd El-Aal

Table (8): Effect of kinetin and NPK fertilization treatments on leaves total carbohydrates and total chlorophylls contents of Hippeastrum vittatum plants during 2010/2011and 2011/2012 seasons.

\begin{tabular}{|c|c|c|c|c|c|c|c|c|c|c|c|}
\hline \multicolumn{12}{|c|}{ First season $(2010 / 2011)$} \\
\hline \multicolumn{2}{|c|}{ Parameters } & \multicolumn{4}{|c|}{ Total carbohydrates (\%) } & \multirow[b]{2}{*}{ Mean } & \multicolumn{4}{|c|}{ Total chlorophylls (mg/100g F.W) } & \multirow[b]{2}{*}{ Mean } \\
\hline \multicolumn{2}{|c|}{ Kinetin Fertilizer } & 0.0 & $\begin{array}{c}2 \\
\text { g/plant }\end{array}$ & $\begin{array}{c}4 \\
\text { g/plant }\end{array}$ & $\begin{array}{c}6 \\
\mathrm{~g} / \text { plant }\end{array}$ & & 0.0 & $\begin{array}{c}2 \\
\text { g/plant }\end{array}$ & $\begin{array}{c}4 \\
\text { g/plant }\end{array}$ & $\begin{array}{c}6 \\
\text { g/plant }\end{array}$ & \\
\hline \multicolumn{2}{|c|}{ Kinetin at $0.0 \mathrm{ppm}$} & 11.96 & 12.63 & 12.93 & 13.16 & 12.67 & 204.3 & 219.4 & 231.8 & 234.2 & 222.4 \\
\hline \multicolumn{2}{|c|}{ Kinetin at $20 \mathrm{ppm}$} & 12.46 & 13.26 & 13.76 & 13.90 & 13.35 & 218.9 & 224.6 & 238.1 & 241.7 & 230.8 \\
\hline \multicolumn{2}{|c|}{ Kinetin at $40 \mathrm{ppm}$} & 12.66 & 13.90 & 13.73 & 14.26 & 13.64 & 229.3 & 234.5 & 242.3 & 245.0 & 237.8 \\
\hline \multicolumn{2}{|c|}{ Kinetin at $60 \mathrm{ppm}$} & 12.80 & 13.86 & 14.36 & 14.63 & 13.91 & 231.7 & 239.1 & 248.2 & 249.6 & 242.2 \\
\hline \multicolumn{2}{|c|}{ Mean } & 12.47 & 13.41 & 13.70 & 13.99 & & 221.1 & 229.4 & 240.1 & 242.6 & \\
\hline \multirow{3}{*}{$\begin{array}{l}\text { L.S.D at } \\
0.05 \text { For }\end{array}$} & kinetin & \multicolumn{5}{|c|}{0.826} & \multicolumn{5}{|c|}{12.36} \\
\hline & fertilizer & \multirow{2}{*}{\multicolumn{5}{|c|}{$\begin{array}{c}0.826 \\
1.65\end{array}$}} & \multicolumn{5}{|c|}{12.36} \\
\hline & interaction & & & & & & & & 24.72 & & \\
\hline \multicolumn{12}{|c|}{ Second season $(2011 / 2012)$} \\
\hline \multicolumn{2}{|c|}{ Kinetin at $0.0 \mathrm{ppm}$} & 12.36 & 1296 & 13.73 & 13.96 & 13.25 & 216.6 & 232.1 & 239.5 & 242.0 & 232.6 \\
\hline \multicolumn{2}{|c|}{ Kinetin at 20 ppm } & 12.73 & 13.86 & 13.63 & 14.13 & 13.59 & 229.2 & 243.2 & 246.3 & 253.6 & 243.1 \\
\hline \multicolumn{2}{|c|}{ Kinetin at $40 \mathrm{ppm}$} & 12.86 & 13.40 & 14.33 & 14.16 & 13.69 & 238.1 & 241.9 & 251.4 & 252.9 & 246.1 \\
\hline \multicolumn{2}{|c|}{ Kinetin at $60 \mathrm{ppm}$} & 12.80 & 13.70 & 14.00 & 14.43 & 13.72 & 241.3 & 245.0 & 252.1 & 256.0 & 248.6 \\
\hline \multicolumn{2}{|c|}{ Mean } & 12.69 & 13.48 & 13.92 & 14.17 & & 231.3 & 240.6 & 247.3 & 251.1 & \\
\hline \multirow{3}{*}{$\begin{array}{l}\text { L.S.D at } \\
0.05 \text { For }\end{array}$} & kinetin & \multirow{2}{*}{\multicolumn{5}{|c|}{$\begin{array}{l}0.859 \\
0.859\end{array}$}} & \multicolumn{5}{|c|}{13.24} \\
\hline & fertilizer & & & & & & \multirow{2}{*}{\multicolumn{5}{|c|}{$\begin{array}{l}13.24 \\
26.48\end{array}$}} \\
\hline & interaction & \multicolumn{5}{|c|}{$\begin{array}{c}0.859 \\
1.72 \\
\end{array}$} & & & & & \\
\hline
\end{tabular}


J. Plant Production, Mansoura Univ., Vol. 5 (3), March, 2014

Table (9): Effect of kinetin and NPK fertilization treatments on endogenous phytohormones of Hippeastrum vittatum plant leaf during 2011/2012 season.

\begin{tabular}{|c|c|c|c|c|c|c|c|c|c|c|c|c|c|c|c|c|}
\hline \multirow{3}{*}{\begin{tabular}{|c}
$\begin{array}{c}\text { Plant } \\
\text { hormones }\end{array}$ \\
Kinetin Fertilizer
\end{tabular}} & \multicolumn{12}{|c|}{ Promoters } & \multirow{2}{*}{\multicolumn{4}{|c|}{$\begin{array}{c}\text { Inhibitors } \\
\text { Abscisic acid (ABA) } \\
\mu \mathrm{g} / \mathrm{g} \text { F.wt. }\end{array}$}} \\
\hline & \multicolumn{4}{|c|}{$\begin{array}{c}\text { Gibberellins }\left(\mathrm{GA}_{3}\right) \\
\mu \mathrm{g} / \mathrm{g} \text { F.wt. }\end{array}$} & \multicolumn{4}{|c|}{$\begin{array}{c}\text { Auxins (IAA) } \\
\mu \mathrm{g} / \mathrm{g} \text { F.wt. }\end{array}$} & \multicolumn{4}{|c|}{$\begin{array}{l}\text { Cytokinins } \\
\mu \mathrm{g} / \mathrm{g} \text { F.wt. }\end{array}$} & & & & \\
\hline & $0.0 \mathrm{~g}$ & $2 g$ & $4 \mathrm{gg}$ & $6 g$ & $0.0 \mathrm{~g}$ & $2 \mathrm{~g}$ & $4 \mathrm{gg}$ & $6 g$ & $0.0 \mathrm{~g}$ & $2 g$ & $\mathbf{4 g}$ & $6 \mathrm{~g}$ & $0.0 \mathrm{~g}$ & $2 \mathrm{~g}$ & $\mathbf{4 g}$ & $6 \mathrm{~g}$ \\
\hline Kinetin at $0.0 \mathrm{ppm}$ & 83.14 & 91.46 & 87.32 & 81.71 & 17.61 & 13.18 & 21.52 & 15.31 & 7.89 & 9.18 & 9.54 & 8.84 & 0.77 & 0.47 & 0.67 & 0.61 \\
\hline Kinetin at $20 \mathrm{ppm}$ & 74.81 & 84.75 & 71.41 & 78.87 & 13.84 & 18.67 & 16.27 & 26.02 & 11.13 & 8.41 & 10.22 & 9.39 & 0.67 & 0.58 & 0.33 & 0.42 \\
\hline Kinetin at $40 \mathrm{ppm}$ & 82.34 & 86.82 & 99.73 & 67.13 & 19.18 & 21.25 & 18.72 & 21.72 & 10.45 & 11.48 & 12.87 & 14.73 & 0.31 & 0.43 & 0.38 & 0.59 \\
\hline Kinetin at $60 \mathrm{ppm}$ & 77.51 & 98.17 & 76.78 & 63.09 & 18.65 & 19.84 & 15.80 & 23.01 & 12.54 & 11.25 & 12.32 & 14.89 & 0.35 & 0.46 & 0.22 & 0.27 \\
\hline
\end{tabular}

Table (10): Effect of kinetin and NPK fertilization on histological characteristics of Hippeastrum vittatum plant leaf (microns) during 2011/2012 season.

\begin{tabular}{|c|c|c|c|c|c|c|c|c|c|c|c|c|c|c|c|c|c|c|c|c|}
\hline \multirow{2}{*}{\begin{tabular}{|l}
$\begin{array}{c}\text { Histological } \\
\text { characteristics }\end{array}$ \\
Kinetin \\
\end{tabular}} & \multicolumn{4}{|c|}{$\begin{array}{l}\text { Upper epidermal } \\
\text { cuticle thickness. }\end{array}$} & \multicolumn{4}{|c|}{$\begin{array}{l}\text { Lower epidermal } \\
\text { cuticle thickness. }\end{array}$} & \multicolumn{4}{|c|}{$\begin{array}{c}\text { Upper epidermal } \\
\text { thickness. }\end{array}$} & \multicolumn{4}{|c|}{$\begin{array}{c}\text { Lower epidermal } \\
\text { thickness. }\end{array}$} & \multicolumn{4}{|c|}{ Thickness of blade. } \\
\hline & $0.0 \mathrm{~g}$ & $2 g$ & $4 g$ & $6 \mathrm{~g}$ & $0.0 \mathrm{~g}$ & $2 \mathrm{~g}$ & $4 \mathrm{~g}$ & $6 \mathrm{~g}$ & $.0 \mathrm{~g}$ & $2 \mathrm{~g}$ & $4 \mathrm{~g}$ & $6 \mathrm{~g}$ & $0.0 \mathrm{~g}$ & $2 \mathrm{~g}$ & $4 \mathrm{~g}$ & $6 \mathrm{~g}$ & $0.0 \mathrm{~g}$ & $2 \mathrm{~g}$ & $4 \mathrm{~g}$ & $6 \mathrm{~g}$ \\
\hline Kinetin at $0.0 \mathrm{ppm}$ & 9 & 13 & & & & 7 & & 8 & & & 37 & & & 31 & & & & & 2927 & 3249 \\
\hline & & & & & & & & & & & & & & & & & & & & \\
\hline & & & & & & & & & & & & & & & & & & & & 77 \\
\hline Kinetin at $60 \mathrm{ppm}$ & 13 & 15 & 17 & 17 & 13 & 12 & 13 & 14 & 39 & 34 & 42 & 47 & 27 & 32 & 41 & 39 & 2495 & 3709 & 4075 & 3924 \\
\hline
\end{tabular}


Table (11): Effect of kinetin and NPK fertilization on histological characteristics of Hippeastrum vittatum plant leaf (microns) during 2011/2012 season.

\begin{tabular}{|c|c|c|c|c|c|c|c|c|c|c|c|c|c|c|c|c|}
\hline \multirow{2}{*}{\begin{tabular}{|c|c|c|}
$\begin{array}{c}\text { Histological } \\
\text { characteristics }\end{array}$ \\
Kinetin Fertilizer
\end{tabular}} & \multicolumn{4}{|c|}{$\begin{array}{l}\text { Thickness of spongy } \\
\text { tissue. }\end{array}$} & \multicolumn{4}{|c|}{$\begin{array}{c}\text { No. of spongy tissue } \\
\text { layers. }\end{array}$} & \multicolumn{4}{|c|}{$\begin{array}{c}\text { Mean thickness of spongy } \\
\text { tissue layer. }\end{array}$} & \multicolumn{4}{|c|}{$\begin{array}{l}\text { Length of vascular } \\
\text { bundle. }\end{array}$} \\
\hline & $0.0 \mathrm{~g}$ & $2 \mathrm{~g}$ & $\mathbf{4 g}$ & $6 \mathrm{~g}$ & $0.0 \mathrm{~g}$ & $2 \mathrm{~g}$ & $\mathbf{4 g}$ & $6 \mathrm{~g}$ & $0.0 \mathrm{~g}$ & $2 \mathrm{~g}$ & $\mathbf{4 g}$ & $6 g$ & $0.0 \mathrm{~g}$ & $2 \mathrm{~g}$ & $\mathbf{4 g}$ & $6 \mathrm{~g}$ \\
\hline Kinetin at $0.0 \mathrm{ppm}$ & 2061 & 2327 & 2548 & 2027 & & & 30 & & & 80.24 & 8193 & & & 247 & 288 & 324 \\
\hline Kinetin at $20 \mathrm{ppm}$ & 2243 & 2517 & 2884 & 294 & 2 & 32 & 35 & 28 & 86.27 & 78.66 & 82.40 & & 277 & 289 & 326 & 328 \\
\hline Kinetir & 2447 & 2621 & & 29 & 3 & 36 & 34 & $3 /$ & & & & & 271 & 315 & 339 & 344 \\
\hline Kinetin at $60 \mathrm{ppm}$ & 2114 & 3308 & 3614 & 3412 & 28 & 35 & 37 & 41 & 75.50 & 94.51 & 97.68 & 83.22 & 289 & 308 & 348 & 395 \\
\hline
\end{tabular}

Table (12): Effect of kinetin and fertilization on histological characteristics of Hippeastrum vittatum plant leaf (microns) during 2011/2012 season.

\begin{tabular}{|c|c|c|c|c|c|c|c|c|c|c|c|c|c|c|c|c|}
\hline $\begin{array}{l}\text { Histological } \\
\text { characteristics }\end{array}$ & \multicolumn{4}{|c|}{$\begin{array}{l}\text { Thickness of phloem } \\
\text { in vascular bundle }\end{array}$} & \multicolumn{4}{|c|}{$\begin{array}{c}\text { Thickness of xylem in } \\
\text { vascular bundle. }\end{array}$} & \multicolumn{4}{|c|}{$\begin{array}{c}\text { No. of vessels in the } \\
\text { vascular bundle. }\end{array}$} & \multicolumn{4}{|c|}{$\begin{array}{c}\text { Thickness of widest } \\
\text { xylem vessel . }\end{array}$} \\
\hline tin $\quad$ Fertilizer & $0.0 \mathrm{~g}$ & $2 g$ & $4 g$ & $6 g$ & $0.0 \mathrm{~g}$ & $2 g$ & $4 \mathrm{~g}$ & $6 g$ & $0.0 \mathrm{~g}$ & $2 g$ & $4 g$ & $6 \mathrm{~g}$ & $0.0 \mathrm{~g}$ & $2 g$ & $4 \mathrm{~g}$ & $6 \mathrm{~g}$ \\
\hline Kinetin at $0.0 \mathrm{ppm}$ & 137 & 143 & 147 & 156 & 81 & 104 & 141 & 168 & 5 & 4 & 6 & 6 & 35 & 42 & 48 & 51 \\
\hline Kinetin at 20 ppm & 134 & 131 & 154 & 172 & 143 & 158 & 172 & 156 & 5 & 6 & 5 & 6 & 41 & 43 & 46 & 57 \\
\hline Kinetin at $40 \mathrm{ppm}$ & 144 & 152 & 161 & 173 & 127 & 163 & 178 & 171 & 5 & 5 & 6 & 7 & 44 & 54 & 61 & 79 \\
\hline Kinetin at $60 \mathrm{ppm}$ & 153 & 143 & 175 & 182 & 136 & 165 & 173 & 213 & 4 & 6 & 7 & 7 & 39 & 52 & 77 & 81 \\
\hline
\end{tabular}


J. Plant Production, Mansoura Univ., Vol. 5 (3), March, 2014

Youssef, A.S.M. and M.M.M. Abd El-Aal

Youssef, A.S.M. and M.M.M. Abd El-Aal

Youssef, A.S.M. and M.M.M. Abd El-Aal

Youssef, A.S.M. and M.M.M. Abd El-Aal

Youssef, A.S.M. and M.M.M. Abd El-Aal

Youssef, A.S.M. and M.M.M. Abd El-Aal

Youssef, A.S.M. and M.M.M. Abd EI-Aal

Youssef, A.S.M. and M.M.M. Abd EI-Aal

Youssef, A.S.M. and M.M.M. Abd El-Aal

Youssef, A.S.M. and M.M.M. Abd El-Aal

Youssef, A.S.M. and M.M.M. Abd El-Aa

Youssef, A.S.M. and M.M.M. Abd EI-Aal

Youssef, A.S.M. and M.M.M. Abd El-Aal

Youssef, A.S.M. and M.M.M. Abd EI-Aal

Youssef, A.S.M. and M.M.M. Abd EI-Aal 
Youssef, A.S.M. and M.M.M. Abd El-Aal

Youssef, A.S.M. and M.M.M. Abd El-Aal

Youssef, A.S.M. and M.M.M. Abd El-Aal

Youssef, A.S.M. and M.M.M. Abd El-Aal

Youssef, A.S.M. and M.M.M. Abd El-Aa

Youssef, A.S.M. and M.M.M. Abd El-Aa

Youssef, A.M and M.M.M. Abd El-Aal 